\title{
Review \\ Eradication of Measurable Residual Disease in AML: A Challenging Clinical Goal
}

\author{
Paolo Bernasconi ${ }^{1,2, *(D)}$ and Oscar Borsani ${ }^{1}$ (D) \\ 1 Department of Molecular Medicine, University of Pavia, 27100 Pavia, Italy; \\ oscar.borsani01@universitadipavia.it \\ 2 Hematology Department, Fondazione IRCCS Policlinico San Matteo, 27100 Pavia, Italy \\ * Correspondence: p.bernasconi@smatteo.pv.it
}

check for

updates

Citation: Bernasconi, P.; Borsani, O. Eradication of Measurable Residual Disease in AML: A Challenging Clinical Goal. Cancers 2021, 13, 3170. https://doi.org/10.3390/cancers13133170

Academic Editor: Andrei Tchirkov

Received: 7 June 2021

Accepted: 19 June 2021

Published: 25 June 2021

Publisher's Note: MDPI stays neutral with regard to jurisdictional claims in published maps and institutional affiliations.

Copyright: (c) 2021 by the authors. Licensee MDPI, Basel, Switzerland. This article is an open access article distributed under the terms and conditions of the Creative Commons Attribution (CC BY) license (https:// creativecommons.org/licenses/by/ $4.0 /)$.
Simple Summary: Relapse is still a major problem in AML because it occurs in about $60-80 \%$ of patients, even those who have previously achieved complete remission (CR), defined by the presence of $\leq 5 \%$ bone marrow (BM) leukemic cells. Thus, since CR is unable to predict the relapse risk, significantly more sensitive techniques aimed at identifying AML cells in BM or peripheral blood, a parameter termed measurable residual disease (MRD), have been developed. Among them, RT-qPCR, which analyses appropriate molecular markers, and multiparameter flow cytometry (MFC), which analyses aberrantly expressed antigens, have been identified as the methods of choice for MRD detection. Nowadays, various studies that assessed MRD by these techniques have provided compelling evidence that MRD positivity (MRD+) after standard induction/consolidation chemotherapy and before allo-HSCT is predictive of a very poor clinical outcome. In addition, other studies, which showed that MRD+ clearance even at late time points of the course of the disease may improve the disease clinical outcome, have further strengthened the relevance of MRD+. Thus, a complete MRD eradication, potentially attainable through novel innovative treatments, has emerged as an un-met clinical need in AML and is expected to improve our patients' prognosis.

Abstract: In non-promyelocytic (non-M3) AML measurable residual disease (MRD) detected by multi-parameter flow cytometry and molecular technologies, which are guided by Consensus-based guidelines and discover very low leukemic cell numbers far below the $5 \%$ threshold of morphological assessment, has emerged as the most relevant predictor of clinical outcome. Currently, it is wellestablished that MRD positivity after standard induction and consolidation chemotherapy, as well as during the period preceding an allogeneic hematopoietic stem cell transplant (allo-HSCT), portends to a significantly inferior relapse-free survival (RFS) and overall survival (OS). In addition, it has become absolutely clear that conversion from an MRD-positive to an MRD-negative state provides a favorable clinical outcome similar to that associated with early MRD negativity. Thus, the complete eradication of MRD, i.e., the clearance of the few leukemic stem cells-which, due to their chemoradiotherapy resistance, might eventually be responsible of disease recurrence-has become an un-met clinical need in AML. Nowadays, this goal might potentially be achieved thanks to the development of novel innovative treatment strategies, including those targeting driver mutations, apoptosis, methylation patterns and leukemic proteins. The aim of this review is to analyze these strategies and to suggest any potential combination able to induce MRD negativity in the pre- and post-HSCT period.

Keywords: AML; MRD; RT-qPCR; MFC

\section{Introduction}

In non-M3 AML, the cytogenetic/molecular categorization of leukemic cells is the most relevant prognostic parameter [1], and for about forty-five years, the achievement of complete remission (CR), defined by the presence of less than 5\% bone marrow (BM) 
leukemic cells on morphological examination, has remained the primary goal of any AML treatment [2]. However, the cure rate of AML patients in CR is still $30-50 \%$ on average, a datum that suggests BM CR is not sufficient to predict the risk of disease relapse [3-6]. Thus, to improve this gloomy clinical outcome, various techniques aimed at identifying $10^{-4}-10^{-6} \mathrm{BM}$ or peripheral blood (PB) leukemic cells (i.e., "Measurable Residual Disease", MRD) in AML patients in morphological CR have been developed [2,7]. The higher sensitivity of these techniques, which include multi-parameter flow cytometry (MFC), reverse quantitative polymerase chain reaction (RT-qPCR), digital droplet PCR (ddPCR) and Next Generation Sequencing (NGS), has allowed for a deeper definition of remission status, thanks to a multimodal assessment of MRD quantification and the immuno-phenotypic and molecular tracking of leukemic cell defects $[5,8,9]$. Today, MFC and RT-qPCR (whose features, along with those of conventional cytogenetics, FISH, ddPCR and NGS, are summarized in Table 1) are considered the methods of choice for MRD detection [7], whereas NGS is a relatively new technique with a still low but improvable sensitivity [10]. Beyond their classical assays, MFC and RT-qPCR may identify which patients are at higher risk of relapse by evaluating the percentage of neoplastic cells at diagnosis [11-13] and analyzing non-stable molecular markers. These last biomarkers, which flag the genotype, phenotype and function heterogeneity of leukemic initiating cells (LICs) $[14,15]$, may promptly identify unique chemo-resistant AML subpopulations not detected on clinical diagnosis but potentially responsible for disease relapse [16-18]. By applying these technologies, various retrospective studies, as well as recent meta-analysis, have proved the negative value of MRD positivity (MRD+) on AML clinical outcome not only in patients submitted to conventional chemotherapy but also in those submitted to allogeneic hematopoietic stem cell transplantation (Allo-HSCT) [19]. In contrast, these same studies and others have revealed that MRD negativity (MRD-) consistently predicts a lower relapse rate (RR) and superior long-term overall survival (OS) [13,20-26] even if about $20-50 \%$ of MRD - patients still relapse. This observation reveals that MRD - as currently assessed does not always provide an absolute certainty of "cure" and strengthens the notion that the MRD threshold should be considered as a moving target that needs to be constantly reset. In addition, MRD assessment is affected by some issues: what is the optimal MRD assay? What is the right time point to perform the assay? What is the influence of MRD status on post-remission treatment strategies? Finally, does the conversion from MRD+ to MRD - during post-remission has any prognostic value? Up until now, this last point has been addressed by one study only, in which post-consolidation MRD- had a significant prognostic influence on five-years relapse-free survival (RFS) and OS independently of the time of its achievement [27]. Despite these limits, MRD is currently employed in the clinic as a routine biomarker for clinical decision making and in clinical trials as a surrogate endpoint to accelerate the discovery and the use of innovative drugs. The development of these innovative drugs, which include small inhibitors of various signal transduction pathways altered by specific gene mutations, regulators of apoptosis, hypo-methylating agents (HMA) and immune checkpoints inhibitors (ICI), remains an area of intensive research in AML. As opposed to standard intensive chemotherapy and allo-HSCT, these new agents allow a more personalized medicine as they specifically target the phenotypic and molecular features of the disease [28]. However, most of these new small molecule inhibitors as single agents have provided unsatisfactory results, probably because multiple "driver" mutations are required for AML development, whereas they have provided successful results when combined with intensive chemotherapy [29]. These findings might suggest that molecular inhibitors, as well as monoclonal antibodies, should be chosen depending on specific mutations or cell surface markers and should always be employed in combination with intensive induction or salvage or maintenance chemotherapy to achieve sounding results. Other investigational drugs that have provided relevant results are those exploring the possibility of overcoming a chemo-resistant phenotype through an immune-based approach and those combining a Bcl-2 inhbitor (venetoclax) with ICI or HMA [5]. This review is aimed at discussing the prognostic MRD power and innovative treatment strategies (excluding cell therapies) 
which might potentially lead to its clearance. The main studies reporting MRD analysis in AML by molecular markers are presented in Table S1 [21,22,30-37]; those based on MFC analysis of MRD are collected in Table S2 [8,9,13,20,25,27,37-57].

Table 1. Technologies for MRD detection in AML.

\begin{tabular}{|c|c|c|c|}
\hline $\begin{array}{l}\text { MRD Assessment } \\
\text { Technology }\end{array}$ & Sensitivity & Advantages & Disadvantages \\
\hline $\begin{array}{l}\text { Conventional } \\
\text { Cytogenetics }\end{array}$ & $\approx 5 \%$ & Standard practice & $\begin{array}{ll}\text { - } & \text { Low sensitivity } \\
\text { - } & \text { Time-consuming and labor-intensive } \\
\text { - } & \text { Can be performed only in patients with } \\
\text { chrom. abnor. at disease onset }(\approx 50 \%)\end{array}$ \\
\hline FISH & $\approx 10^{-2}$ & $\begin{array}{l}\text { Useful for numerical } \\
\text { chromosomal } \\
\text { abnormalities }\end{array}$ & $\begin{array}{l}\text { - } \quad \text { Lower sensitivity in comparison to MFC } \\
\text { or RT-qPCR } \\
\text { - Can be performed only in patients with } \\
\text { chrom. abnor. at disease onset }(\approx 50 \%)\end{array}$ \\
\hline MFC-LAIP & $10^{-3}-10^{-5}$ & $\begin{array}{ll}- & \text { Sensitive } \\
- & \text { Extensively available } \\
- & \text { Can be performed in } \\
& >90 \% \text { of patients } \\
\text { - } & \text { Fast }\end{array}$ & $\begin{array}{ll}\text { - } & \text { Need of diagnostic samples } \\
\text { - } & \text { Need of large antibody panels } \\
\text { - } & \text { Does not evaluate } \\
\text { - } & \text { immune-phenotypic shifts } \\
\text { - } & \text { Requires technical expertise } \\
& \text { Limited standardization } \\
\text { across laboratories }\end{array}$ \\
\hline MFC-DfN & $10^{-3}-10^{-5}$ & $\begin{array}{ll}\text { - } & \text { Sensitive } \\
\text { - } & \text { No need for } \\
\text { diagnostic samples } \\
\text { - } \quad \begin{array}{l}\text { Results not influenced } \\
\text { by immunophenotypic }\end{array} \\
\text { shifts } \\
\text { Can be performed in } \\
\text { - } 90 \% \text { of patients } \\
\text { Fast }\end{array}$ & $\begin{array}{ll}\text { - } & \text { Requires a significant technical expertise } \\
\text { - } & \text { Limited standardization } \\
\text { across laboratories }\end{array}$ \\
\hline RT-qPCR & $10^{-4}-10^{-6}$ & $\begin{array}{ll}\text { - } & \text { Sensitive } \\
\text { - } & \text { Well standardized } \\
\text { - } & \text { Common practice in } \\
& \text { various laboratories }\end{array}$ & $\begin{array}{ll}\text { - } & \text { Suitable targets in }<50-60 \% \text { of patients } \\
\text { (in }<35 \% \text { of elderly patients) } \\
\text { - } \quad \text { Many mutations not suitable for MRD } \\
\text { (e.g., FLT3) } \\
\text { - } \quad \text { Time-consuming and labor-intensive } \\
\text { - } \quad \text { In some cases, results after several days }\end{array}$ \\
\hline ddPCR & $10^{-4}-10^{-6}$ & 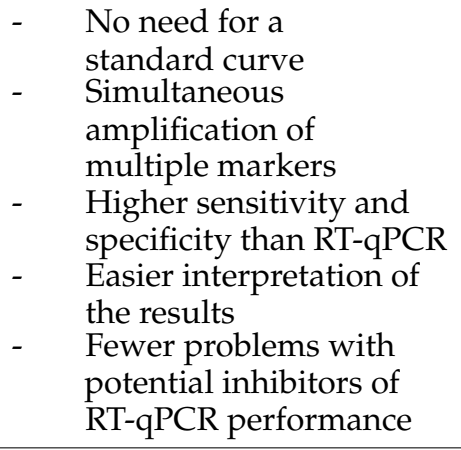 & $\begin{array}{ll}\text { - } & \text { Suitable targets in }<50-60 \% \text { of patients } \\
\text { (in }<35 \% \text { of elderly patients) } \\
\text { - Many mutations not suitable for MRD } \\
\text { (e.g., FLT3) } \\
\text { - Less time-consuming and } \\
\text { labor-intensive than RT-qPCR } \\
\text { - Limited numbers of } \\
\text { experienced laboratories } \\
\text { - Not recommended outside clinical trials }\end{array}$ \\
\hline NGS & $\begin{array}{l}\text { Extremely } \\
\text { variable } \\
\left(1-10^{-6}\right)\end{array}$ & $\begin{array}{l}\text { - Sensitivity potentially } \\
\text { high and dependent on } \\
\text { the technology applied } \\
\text { - Can simultaneously } \\
\text { examine multiple genes }\end{array}$ & $\begin{array}{ll}\text { - } & \text { Low sensitivity with common platforms } \\
\text { - } & \text { Persistence of pre-leukemic mutations } \\
\text { - } & \text { may be confounding (e.g., CHIP) } \\
\text { - } & \text { Expensive } \\
\text { - } & \text { Not standardized } \\
\text { - } & \text { Bioinformatics required for interpreting } \\
\text { the results }\end{array}$ \\
\hline
\end{tabular}




\section{The Prognostic Value of MRD}

\subsection{MRD Assessment after Induction/Consolidation}

In contrast to acute lymphoblastic leukemia for which MRD assessment is the standard of care, MRD assessment in AML has always been hampered by difficulties in standardization and uncertainties over its prognostic power [58]. However, various studies have demonstrated that, based on MRD assay results, AML patients in CR can be effectively stratified in different subgroups having distinct RR and OS. The strict link between a positive MRD assay and an inferior clinical outcome has been proved at several time-points during AML treatment history, independently of the MRD assay employed. This tight association has been revealed by past studies [59-61] and numerous more recent studies [62,63]. As far as RUNX1-RUNX1T1 goes, one study employed this molecular marker for disease monitoring at the end of treatment [30] and one during the follow-up period [58]. In one study, BM MRD did not predict subsequent relapse, which was instead predicted by PB MRD [30], whereas in the other study BM and PB MRD were equally effective in predicting relapse [58]. In addition, one study revealed that a $>10$ copy number reduction of PB CBFB-MYH11 predicted RR but not OS [31] and noted that a constant increase of MRD during the follow-up period was predictive of morphological disease recurrence. Other studies employed NPM1 mutation (NPM1m) as a molecular marker at different time points $[21,22,33,34]$. All these studies showed that patients who remained NPM1 positive (NPM1+) in PB or BM after the second course of chemotherapy or at the end of treatment presented a higher RR and a lower OS than those of NPM1-negative (NPM1-) patients. In addition, one study revealed that MRD+ in PB after the second course of chemotherapy was more informative than at any other time point [21]. In patients in CR but still MRD+ in PB after the second course of chemotherapy, multivariate analysis identified DNMT3A and FLT3-ITD mutations (high-risk mutations) as independent risk factors for RR and OS. Interestingly, MRD+ in PB was associated with a higher Medical Research Council (MRC) risk score and with a higher probability of carrying the FLT3-ITD mutation. In addition, in these MRD+ patients, the presence of either the FLT3-ITD mutation or the DNMT3A mutation determined a clinical outcome significantly inferior than that of MRD- patients, but in patients who were MRD - in PB after the second course of chemotherapy, the presence of either mutation determined a favorable clinical outcome [21]. A validation cohort of ninety-one patients confirmed these results by identifying a subgroup of NPM1+ patients without any FLT3-ITD mutations who presented a 2-year cumulative incidence of relapse (CIR), significantly higher than that of NPM1 - patients. This result was also achieved by a French study that evaluated whether post-induction MRD in NPM1m patients may identify patients who may benefit from allo-HSCT and fixed the MRD threshold to $\geq 4 \log 10$ reduction, predicting the lowest CIR and the best OS in multivariate analysis [22]. In this study, MRD analysis performed by searching for NPM1 $m$ identified a subgroup of FLT3ITD-positive (FLT3-ITD+) patients who presented a relatively good clinical outcome, even if, as reported by other studies [64,65], a high FLT3-ITD allelic ratio predicted a poor clinical outcome in univariate but not in multivariate analysis. More importantly, in this study, only patients of the not-favorable category who achieved an NPM1m PB MRD < 4-log benefited from allo-HSCT. Other studies emphasized the prognostic role of the FLT3-ITD allelic ratio, supporting its evaluation, especially from a transplant perspective $[65,66]$.

As already reported, MFC is the other method routinely employed for MRD detection (the most relevant studies performed in pediatric and adult patients that used MFC for MRD detection are listed in Table S2).

The demonstration that MFC-detected MRD+ after induction chemotherapy predicted a high CIR independent of the time at which patients had achieved CR was definitively proven by a study that used a leukemia-associated aberrant immunophenotype (LAIP) approach [13] and by two other studies that employed the same strategy to show the poor prognostic influence of pre-transplant MRD+ [48,67]. In addition, another study revealed that MRD+ identified by MFC through a LAIP approach maintained its prognostic value even at sixteen-eighteen days post-induction chemotherapy [50]. Subsequently, another 
report that evaluated MRD prior and after allo-HSCT found that only pre-transplant MRD+ was predictive of an inferior RFS and OS, which were not affected by MRD clearance threefive weeks post-transplant [51], an observation that contrasts with a GIMEMA/EORTC study that suggested allo-HSCT might overcome the outcome related to MRD+ [68]. More currently, MFC was employed to determine MRD after the first (C1) and the second course (C2) of intensive induction chemotherapy in NPM1 wild-type (NPM1wt) standard-risk AML to redefine the partial response (PR) and achieve better patient stratification [24]. In this study, MRD status was more predictive for relapse and overall survival at $\mathrm{C} 2$ than at $\mathrm{C} 1$. After C1, the five-year OS of MRD+ patients in the good and standard risk category in PR was similar and significantly different to that of patients with a resistant disease; after $\mathrm{C} 2$, the four-year RFS and the RR of the good and standard risk categories were significantly different between MRD+ and MRD- patients. Importantly, MRD+ patients in these risk categories were the only ones who benefited from allo-HSCT, an observation confirmed by a recent GIMEMA study that used post-consolidation MRD to choose the best post-remission strategy in young de novo AML [56]. This study reported that MRD+ patients in the intermediate risk category were those who benefited from allo-HSCT, which made their disease-free survival (DFS) and OS similar to those of patients in the favorable risk category.

Fewer study used NGS for MRD assessment. A study that performed paired whole genomic or exon sequencing on samples collected at diagnosis and at remission revealed that a variant allele frequency (VAF) $\geq 2.5 \%$ identified patients with a poor clinical outcome among those who harbored AML-specific mutations in $\geq 5 \%$ of BM residual leukemic cells [69]. A subsequent study that used the same approach reported that VAF-based mutation clearance (MC) of 1 and a complete $M C(C M C)$ were associated with a significantly better OS and lower CIR and that [70] CMC was associated with significantly better event-free survival (EFS), especially when pre-leukemic mutations were not included in the analysis. The same conclusion was achieved by another study, which suggested that NGS-determined MRD may add prognostic value to MFC-determined MRD [25]. However, since NGS still has a low sensitivity that severely affects its MRD detection threshold, a current study has developed a molecular barcoded approach, which may identify residual mutations at a lower VAF (median VAF 0.33\%, range 0.016-4.91\%) [10]. This approach was able to precisely identify MRD+ patients who, in multivariate analysis, presented a five-year CIR significantly higher than that of MRD- patients (66\% versus 17\%).

\subsection{Peri-alloHSCT MRD Assessment}

As already reported, MRD may be used to guide post-remission strategies, among which allo-HSCT plays a relevant role as post-transplant relapse has an incidence lower than that of post-chemotherapy relapse [19]. Past studies have revealed no difference in the incidence of the post-transplant AML relapse between MRD+ and MRD- patients [71], but peri-transplant MRD status is still considered a critical parameter for post-transplant clinical outcome [72]. Some studies have demonstrated that allo-HSCT can only overcome the poor prognosis of pre-transplant MRD+ in patients included in the low-risk genetic category $[26,51,73]$, whereas other studies have reported that this may also occur for patients included in the intermediate risk category $[26,51,73]$. The clinical effectiveness of allo-HSCT has been confirmed by a study in which two courses of consolidation or loss of molecular response six months after molecular remission distinguished patients in low- and high-risk depending on RUNX1-RUNX1T1 MRD status. In this study, high-risk patients who received an allo-HSCT presented a significantly lower CIR and better OS than high-risk patients who did not receive an allo-HSCT [32]. More recently, another study revealed that pre-transplant MRD remained a significant variable for post-transplant outcome in patients with a monosomal karyotype, the statistical influence of which was lost in multivariate analysis [74]. Another study evaluated whether NPM1 analysis as a pre-transplant molecular MRD could be more effective in predicting a relapse than pretransplant MFC MRD [37]. After 4.9 years of median follow-up, NPM1 MRD analysis 
allowed us to distinguish three patient subgroups with distinct 2-year OS. MRD+ and FLT3-ITD + in the pre-transplant period presented a significantly poor clinical outcome, and by combining these variables, two distinct subgroups of patients with a significantly different two-year OS were identified (17\% versus $82 \%)$. In addition, a significant reduction in OS was associated with T-cell depletion and MRD+ but was not associated with conditioning intensity and donor source. Even more currently, the prognostic value of CR and MRD status was assessed in relapsed/refractory AML [57]. In this study, CR and MRD - identified patients had the lowest 2-year CIR, better 2-y RFS and a trend toward a better OS.

Based on these data, many studies have questioned whether conditioning intensity may overcome the poor prognostic significance of MRD+ and influence post-transplant RR. Some retrospective studies have already reported that RR was lower with myelo-ablative conditioning (MAC) than with reduced intensity conditioning (RIC) and with non-myeloablative (NMA) conditioning [75,76], whereas other prospective studies have reported that MAC in CR1 patients aged 40-60 years included in the intermediate-/high-risk cytogenetic category did not provide any benefit in comparison with RIC [77-79]. Subsequently, it was revealed that in patients who received a MAC regimen after either an umbilical cord blood or a sibling donor HSCT, MRD status did not influence the clinical outcome, whereas in those who received a RIC regimen, MRD status had a significant influence on the RR [80]. This observation was confirmed by a randomized phase 3 BMT CTN 091 study, which enrolled younger patients in morphological CR. This study, which was ceased due to the high RR associated with RIC, established that MAC should be the standard of care for fit patients with AML or myelodysplastic syndrome (MDS) [81]. These results were partially confirmed by a subsequent EBMT retrospective study, which analyzed the clinical outcome of AML patients who received allo-HSCT in CR1 [82]. This study reported that in MRD+ patients aged $<50$ years, MAC determined an RR lower than RIC/NMA, whereas in MRD - patients aged $<50$ years, it determined similar clinical outcomes with a higher chronic graft-versus-host disease (cGvHD) incidence. In patients aged $>50$ years, MAC provided no benefit regardless of MRD status. More recently another study confirmed these results [83]. More currently, and in contrast with the above studies, the Fred Hutchinson Cancer Research Center reported that MAC determines longer RFS and OS but similar RR in comparison to RIC and NMA conditioning [84]. Importantly, in MRD+ patients, MAC determined RR and OS similar to RIC and NMA, whereas in MRD- patients, it determined a better clinical outcome in comparison to RIC and NMA (3-y OS and RFS 69\% and 71\% vs. $47 \%$ and $55 \%$ for RIC vs. $47 \%$ and $52 \%$ for NMA; 3 -y RR $18 \%$ vs. $30 \%$ for RIC and NMA). In addition, in 2020 the EBMT Acute Leukemia Working Party evaluated the curative potential of the conditioning intensity in CR2 AML patients [85]. This study, which performed alloHSCT from any type of donor, revealed that in patients aged $<50$ years, MAC and RIC regimens provided similar clinical outcomes, whereas in patients aged $>50$ years, MAC provided significantly reduced non-relapse mortality (NRM). For completeness, it must be remembered that in relapsed/refractory AML, other studies have explored the role of sequential chemotherapy in addition to RIC in determining MRD clearance but have never achieved this goal [86-88].

Another issue analyzed by various studies is whether donor choice may affect alloHSCT's ability to overcome MRD+. Among the few retrospective studies that have analyzed this topic, the most relevant one reported that, similarly to MRD+ patients who received the transplant from a matched unrelated donor (MUD), MRD+ patients who received the transplant from a mismatched unrelated donor (mMUD) presented a significantly worse clinical outcome than patients who received a cord blood transplant [89]. In contrast, in MRD - patients, transplantation from either MMUD, MUD or cord blood provided similar clinical outcomes. 


\subsection{How to Achieve MRD Clearance? \\ Consolidation Chemotherapy}

EBMT and CIBMTR studies have demonstrated that in patients undergoing MAC or RIC conditioning, pre-transplant consolidation does not provide any advantage as far as CIR and RFS are concerned [90-93]. However, these studies evaluated neither pre-transplant MRD status nor MRD kinetic clearance, an issue deeply analyzed by GIMEMA/EORTC protocol [9]. This last, which assessed MRD by MFC, underlined the utmost relevance and statistically significant influence of MRD- on clinical outcome independent of the time at which it was achieved and once more underscored the need to maintain MRD-. In this study, consolidation treatment was able to convert MRD+ into MRD - in ten patients who were MRD+ after induction, but it was not able to maintain MRD - in nine patients who were MRD - after induction.

\subsection{Targeting Driver Mutations and Oncogenic Pathways}

\subsubsection{FLT3 Inhibitors}

Various FLT3 inhibitors distinguished in multi-kinase versus selective FLT3 inhibitors and in type 1 versus type 2 inhibitors have been developed [94]. Monotherapy with type 1 inhibitors, except for sorafenib, has always provided unsatisfactory results. Instead, a study that evaluated sorafenib monotherapy in patients who relapsed post-transplant and in those who relapsed post-chemotherapy reported a complete molecular response of $25 \%$ versus $8 \%$ and the development of sorafenib resistance in $38 \%$ versus $47 \%$ of patients, with sorafenib resistance occurring 197 versus 137 days after sorafenib start [95]. Another report suggested that the sorafenib anti-leukemia activity was due to the fact that it induced a high release of IL15 from ITD+ leukemic cells, an event that determined a boost in CD8/CD107a/IFN $\gamma$-positive T-cells with a longevity pattern (high Bcl-2 and low PD-1 expression) [96]. In addition, it was reported that three patients who responded to sorafenib treatment administered for a post-transplant relapse presented skin infiltration by CD3+ T-cells and BM infiltration by CD3/CD8/CD279-positive lymphocytes [97].

In comparison to type 1 inhibitors, monotherapy with type 2 inhibitors provided more successful results $[98,99]$. However, in a phase III study, quizartinib monotherapy did not reach FDA approval, despite the fact that in comparison to salvage chemotherapy it caused a $24 \%$ reduction of the risk of death, improved OS (6.2 versus 4.7 months) and the 1-year survival rate ( $27 \%$ versus $20 \%)$, as well as allowing more patients to undergo allo-HSCT (32\% versus 11\%) [100]. Instead, the $37-40 \%$ CR rate achieved by gilteritinib monotherapy in phase I/II studies [101] prompted a phase III study that led to gilteritinib approval for relapsed/refractory AML [102]. These successful results and the synergism between FLT3 inhibitors and chemotherapy founded the rational for combining type 2 FLT3 inhibitors with standard induction/consolidation chemotherapy. A phase III study that compared midostaurin plus induction chemotherapy versus chemotherapy alone reported similar CR rates (58.9\% versus 53.5\%) but superior median OS (74.7 versus 25.2 months), EFS (8.2 versus 3.0 months), DFS (26.7 versus 15.5 months) and 4-year OS (51.4\% versus $44.2 \%)$ for the midostaurin arm [103]. Midostaurin OS was not affected by the type of mutation whereas EFS was better for TKD+ patients. The results achieved by this study might indicate that midostaurin induces deeper remissions than salvage chemotherapy, a clinical status that should be exploited as soon as possible: patients on midostaurin arm transplanted in CR1 presented a trend towards a better 4-year OS when compared with patients on chemotherapy transplanted in CR1 (63.7\% versus 55.7\%), an advantage that was lost when patients were transplanted in subsequent CRs. Another phase II study confirmed these results [104].

The clinical efficacy of other type 2 inhibitors was revealed by a phase II study (crenolanib as a 1-year maintenance treatment combined with chemotherapy induced a CR in $83 \%$ of patients, $80 \%$ of whom achieved MRD negativity on MFC) [105] and a phase Ib study (quizartinib) [106]. More currently, a phase I/II study that combined standard induction/consolidation with gilteritinib in two escalating doses fixed the gilteritinib maxi- 
mum tolerated dose at $120 \mathrm{mg}$ /day and reported a 100\% composite CR rate for patients on schedule 1 versus $81.8 \%$ for patients on schedule 2 with a median DFS of 297 days [107]. Based on these exciting results, various studies are evaluating the role of these inhibitors as post-transplant maintenance [108]. A study reported that in comparison with historical controls, sorafenib maintenance significantly improved 2-year OS (81\% versus 62\%), 2-year PFS (82\% versus 52\%) and 2-year RI (8\% versus 38\%) and determined a similar 2-years NRM and cGVHD [109]. Another randomized, double-blind placebo-controlled trial confirmed sorafenib efficacy in preventing relapse [110], and a subsequent EBMT retrospective multi-centric study reported that sorafenib maintenance significantly improved 2-year OS (83\% versus 62\%), 2-year DFS (79\% versus 62\%), GvHD relapse-free survival (GRFS) and CIR in comparison with historical controls [111]. Based on these data, a randomized, double-blind, placebo-controlled phase III trial is comparing gilteritinib versus placebo [112].

\subsubsection{Isocitrate Dehydrogenase 1 and 2 (IDH1/IDH2) Inhibitors}

Monotherapy with ivosidenib has been approved for the treatment of newly diagnosed $I D H 1+$ relapsed/refractory AML patients not eligible for standard chemotherapy due to the results obtained by two studies $[113,114]$. The first study reported a CR of nine months duration in $22 \%$ of patients and a median overall response rate (ORR) of $42 \%$, the duration of which was nine months, as well as no residual IDH1 mutation in seven patients; the second study reported a CR + CR with incomplete hematological recovery (CRi) of "not reached" duration in $42 \%$ of patients and a $64 \%$ IDH1 mutation clearance [114]. Instead, in a dose-escalation and expansion phase I study performed in IDH2+ relapsed/refractory AML monotherapy with enasidenib, the oral IDH2 inhibitor determined a $20 \%$ CR rate and a $40 \%$ ORR [115]. Similar results were also obtained by a subsequent first-in-human study, which reported similar CR and OR rates without any difference between IDH2-R140 and IDH2R170 mutations, an OS of almost two-years in responding patients and the achievement of transfusion independence. IDH2 mutation clearance was associated with a $100 \%$ clinical response rate and allowed allo-HSCT in 10\% of responsive patients [116]. Moreover, in a phase I/II trial, which enrolled older patients with an antecedent hematological disorder, enasidenib induced a 30\% ORR and a 18\% CR rate [117]. Interestingly when these IDH1 and IDH2 inhibitors were combined with standard chemotherapy in de novo and secondary AML, ivosidenib determined a CR rate of $93 \%$ and $73 \%$ and enasidenib determined a CR rate of $73 \%$ and $63 \%$ [118]. More importantly, IDH1 and IDH2 mutation clearance occurred in $41 \%$ and $30 \%$ of patients and MFC-MRD negativity in $89 \%$ and $59 \%$ of patients.

\subsubsection{Inhibitors of the Hedgehog (Hh) Signaling Pathway}

Since the aberrant activation of this signaling pathway occurs in many myeloid disorders [119], glasdegib, a potent and selective sonic hedgehog receptor smoothened (SMO) inhibitor which reduces the LIC number has also been tested in AML clinical trials [120]. Various phase I studies have fixed the glasdegib recommended dose to $100 \mathrm{mg}$ [121], and a randomized, open-label, multicenter phase II trial has compared glasdegib plus lowdose cytosine-arabinoside (LDAC) versus LDAC alone, leading to glasdegib + LDAC approval for newly diagnosed AML aged $\geq 75$ years and for patients not fit for intensive chemotherapy due to co-morbidities because of a better clinical outcome with this drug combination [122]. Another phase II trial, which tested glasdegib clinical efficacy in MDS patients who had failed HMA, reported that after a median follow-up of 42.8 months, OR was $6 \%$ and median OS was 10.4 months [123], confirmed by another multicenter open-label randomized phase II trial [124]. More recently, a dual center pilot study tested glasdegib's ability to prevent post-allo-HSCT relapse in AML/MDS who had achieved a stable engraftment twenty-eight days post-transplant [125]. Glasdegib was started after a median time of 46 days post-transplant and was permanently discontinued after a median time of one-hundred forty-two days and continued for one year in eight patients. At day +80 , all patients except one did not show any MRD. Relapse was revealed by MFC 
at a median of 180 days post-transplant, whereas morphological relapse occurred at a median days of 333 days post-transplant. In all patients, 1- and 2-year RFS rates were $41.9 \%$ and $31.5 \%$ and 1-year CIR (MRD+ and morphological relapses) was $45.2 \%$, whereas in MFC-MRD+ patients, 1- and 2-year RFS were 30\% and 16.7\% and one-year CIR was $55 \%$. The conclusion of this study is that glasdegib does not reduce the post-transplant relapse probability.

\subsection{Targeting Apoptotic Pathways \\ 2.5.1. BCL2 Inhibitors}

A phase I/II study has revealed that venetoclax, a selective BCL2 inhibitor, combined with HMA or with LDAC yielded $45 \% / 30 \%$ MRD negativity in treatment-naïve elderly patients ineligible for intensive chemotherapy who achieved CR/CRi [126,127], a result confirmed by another study [128]. In this study, after a median follow-up of 8.9 months, CR/CRi were $67 \%$, with a CR/Cri of $73 \%$ for patients on venetoclax and a median OS of 17.5 months for all patients versus "not reached" for those on $400 \mathrm{mg}$ of venetoclax [128]. The updated results of this study were extremely encouraging: CR/CRi rate was 54\%, median OS was 10.1 months, median response duration was 8.1 months and mortality rate was $6 \%$ [129]. These sounding results not only led to the approval of these drug combinations in newly diagnosed elderly AML patients but also to the evaluation of the clinical efficacy of venetoclax combined with various schedules of intensive chemotherapy in younger newly diagnosed AML patients. Wei and co-authors [109] reported a CR/CRi rate of 71\% (95\% in newly diagnosed AML versus $42 \%$ in secondary AML) and response rates of 90\% for NPM1, RUNX1, and IDH1 mutated patients versus 33\% for TP53 mutated patients. At interim analysis, another phase $\mathrm{Ib} / \mathrm{II}$ study reported a median time of twenty-seven days to achieve the best response and 85\% CR/CRi and MRD negativity rates, including a $60 \%$ CR/CRi rate in TP53-mutated patients [130]. Another phase II study evaluating venetoclax plus two courses with cladribine and LDAC, alternated with two courses of azacitidine, in elderly newly diagnosed AML ineligible for intensive chemotherapy is still ongoing. At interim analysis, CR/CRi and MRD negativity rates were $89 \%$ and $84 \%$ versus 55\% for patients with high-risk cytogenetics [131].

Currently, ongoing studies are exploring venetoclax combined with IDH1/IDH2 and FLT3 inhibitors and with agents restoring p53 activity. A phase I/II study, which explored venetoclax + ivosidenib with or without azacitidine in these AML patients, reported $89 \%$ of the overall CR/CRi rate, which varied in relation to venetoclax doses $(100 \%$ for ivosidenib + venetoclax $800 \mathrm{mg}$, 67\% for ivodenisib + venetoclax $400 \mathrm{mg}$ and $67 \%$ for ivodenisib + venetoclax $400 \mathrm{mg}+$ azacitidine) [132]. Since FLT3-ITD may determine venetoclax resistance by inducing high BCL-XL and MCL1 levels but in vitro studies have shown a synergistic activity between venetoclax and quizartinib [133], a phase Ib study is evaluating venetoclax + gilteritinib in relapsed/refractory AML [134]. This study reported a preliminary CR/CRi rate of $20 \%$ in FLT3 wild-type patients versus $88 \%$ in FLT3-mutated patients. Other ongoing studies are evaluating venetoclax + quizartinib (NCT03735875) and venetoclax + HMA + FLT3 TKI in FLT3-mutated relapsed/refractory AML (NCT03661307) and in newly diagnosed AML ineligible to intensive chemotherapy (NCT04140487). Venetoclax was also tested in combination with HMA in TP53-mutated patients, but results were disappointing [128]. Instead, preclinical studies have suggested an anticancer synergism between venetoclax and idasanutlin, a MDM2 inhibitor $[135,136]$, so that these two drugs were combined in a phase IB study in elderly relapsed/refractory AML patients ineligible for intensive chemotherapy, which provided interesting results [137].

\subsubsection{Hypomethylating Agents}

Treatment with HMA (azacitidine and decitabine) have been approved for MDS and AML patients ineligible for chemotherapy, and various studies have revealed that HMA could eradicate persistent MRD, especially in high-risk AML patients [138,139]. The RELAZA2 trial, which monitored NPM1m and fusion gene rearrangements by RT-qPCR and 
donor chimerism by flow cytometry on sorted CD34+ cells during a twenty-four-month follow-up period in one hundred and ninety-eight AML/MDS MRD+ patients in CR after chemotherapy or allo-HSCT, has further strengthened azacitidine clinical efficacy [138]. Thirty-one of the fifty-three MRD+ patients who received azacytidine at standard doses for up to twenty-four cycles were relapse-free and alive six month after azacitidine start. In addition, during a median follow-up of twenty-three months, nineteen of the fifty-three MRD+ patients became MRD-, and twelve of these nineteen patients remained MRD- without any clinical relapse. After a median follow-up of thirteen months, RFS at twelve months for all the fifty-three MRD+ patients was $46 \%$ versus $88 \%$ for MRD- patients. It was noteworthy that a significantly improved RFS and a trend towards an improved OS were noted in patients who converted from MRD+ to MRD-. However, HMA clinical efficacy was not confirmed by other clinical trials [140].

\subsection{Immune Targets \\ Immune Checkpoint Inhibitors}

Several studies showed that response to ICI required the presence of T-cells within the tumor microenvironment and that the presence and the amount of those T-cells could be a reliable marker to predict the response to ICI in various hematologic and solid malignancies [141-144]. In line with this evidence, other studies have shown a greater effect of ICI when this therapy was used to treat tumors with a higher expression of PD- 1 and CTLA-4 on tumor-infiltrating T-cells and a higher expression of PD-L1 on neoplastic cells. Moreover, data obtained by clinical trials regarding patients with non-small-cell lung cancer and melanoma showed that a significant clinical response could be obtained even in patients with a low expression of PD-L1 [145-147]. Furthermore, other studies showed that the co-stimulatory molecules CD80 and CD86 are also expressed by leukemic cells in AML and MDS, but data about the prognostic impact of this finding are controversial [148-150] (Figure 1). Subsequent studies demonstrated that those AML patients with a lower likelihood of response to HMA and with a poorer prognosis have a significantly increased expression of PD-L1 and PD-L2 on leukemic cells [151,152]. Increased bone marrow PD-1+ T-cells was found in patients with relapsed AML [153]. Finally, an increased amount of circulating regulatory T-cells in patients with AML and their persistence after induction chemotherapy has been associated with a higher risk of relapse [154-156].

In AML, there is a scarcity of data regarding the composition of the tumor microenvironment within bone marrow as far as the expression of immune checkpoint receptors, T-cell functionality, and the distribution of various T-cell subsets are concerned. The mechanism of action of immune checkpoint blockade (ICB) implies the presence of T-cells within the tumor microenvironment. This has been suggested by several studies that reported a significantly increased percentage of T-cells in the bone marrow of AML patients compared with healthy individuals [157-159]. Other studies showed that, despite peripheral T-cells seeming to have normal functions in response to co-stimulatory signals, T-cells residing in the bone marrow showed an overexpression of PD-1 (i.e., one of the most important inhibitory immune checkpoint receptor) and use of PD-1 inhibitor could overcome the inhibitory signals transduced by PD-1 [160,161].

In AML the differentiation and activation status of T-cells is as important as their number and distribution. The anti-neoplastic activity of CD8+ T-cells is directly based on the release of perforin and granzyme $B$ to induce target cell apoptosis. On the other hand, CD4+ T-cells, depending on the cytokine network in the tumor microenvironment, differentiate into various types of effector cells, even including regulatory T-cells. There are discordant data about the role of CD8+/CD4+ T-cell ratio: in one study, a higher CD8+/CD4+-ratio was found in healthy controls and normalized after chemotherapy, but other studies failed to reproduce this finding $[159,162]$. One of the mechanisms involved in the immune escape of leukemic cells is called "T-cell exhaustion" and consists of an increased expression of various inhibitory receptors (e.g., TIGIT, LAG-3, TIM-3, PD-1), which hamper normal T-cell proliferation and cytokine production [143]. This mechanism was 
supported by a recent study, which showed that LILRB4, an inhibitory T-cell receptor, was involved in immune escape by leukemic cells [163]. The mechanism of T-cell exhaustion seems to be prevalent in the bone marrow of patients with relapsed AML and may be a consequence of both persistent antigen stimulation and exposure to multiple lines of prior chemotherapies [160,164,165].

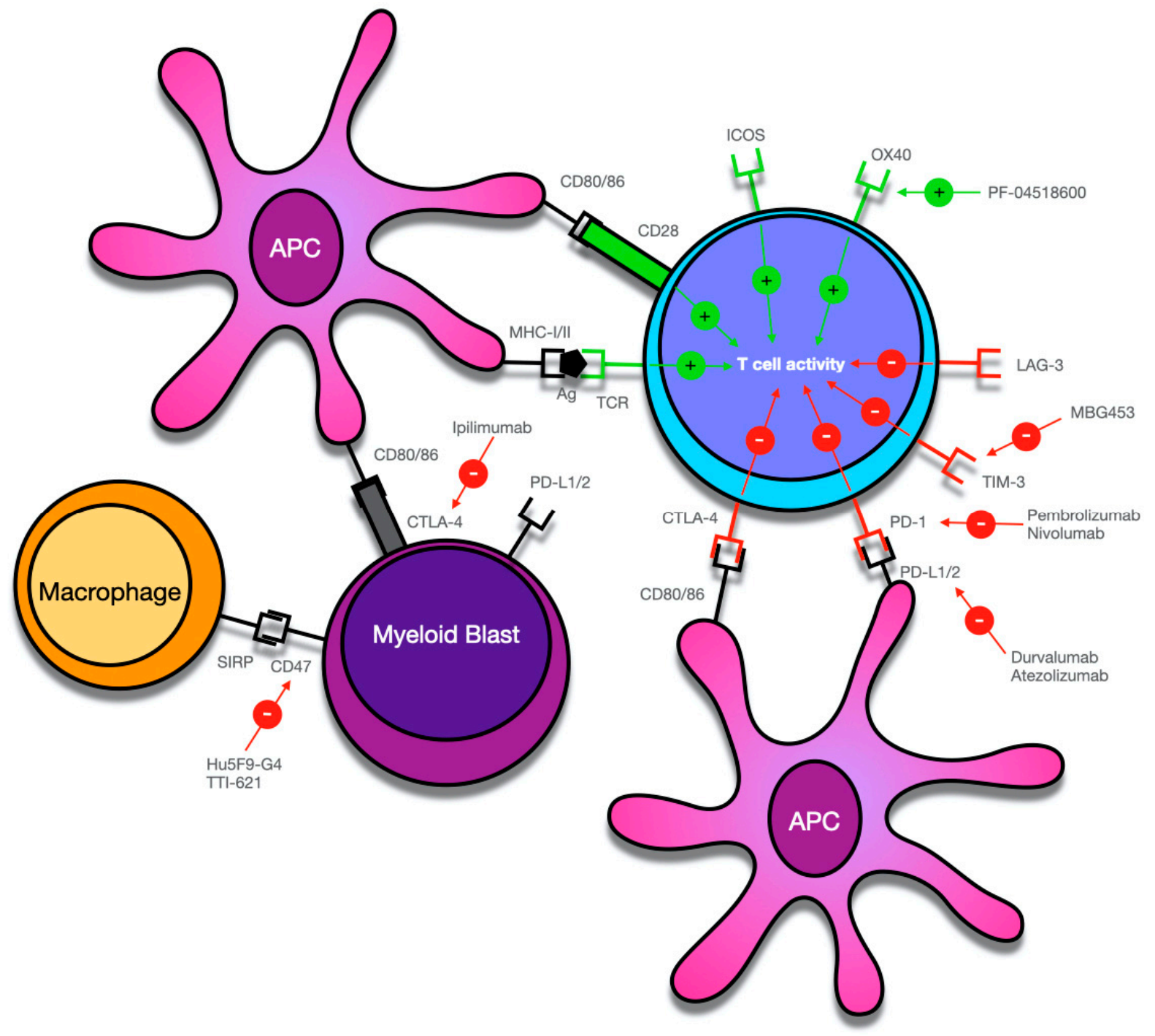

Figure 1. Overview of potential targets for immune checkpoint-mediated therapy in myeloid malignancies. Antigens (Ag), including tumor antigens, are bound to major histocompatibility complex (MHC)-I/II molecules by antigen-presenting cells (APC) and activate T-cells by binding to the T-cell receptor (TCR). Co-stimulatory signals such as activation of CD28 on T-cells by CD80 or CD86 is required for T-cell activation. The activity of T-cells is further regulated by various co-inhibitory (PD-1, CTLA-4, TIM-3, LAG-3) and co-stimulatory receptors (ICOS, OX-40), which can serve as potential targets for monoclonal antibodies that mainly block the activity of co-inhibitory receptors. However, as in the case of PF-04518600, activating co-stimulatory receptors can also be employed to increase the anti-tumor immune response. Myeloid blasts can also express various receptors on their surfaces, which create an immunosuppressive microenvironment and can contribute to immune system evasion. While thus far, T-cells have been the main focus of immune checkpoint-mediated therapy, current research has also identified the interaction of CD47 on APCs and myeloid blasts and SIRP $\alpha$ on macrophages as a potentially targetable mechanism of checkpoint therapy.

Within the bone marrow, an intricate interplay between myeloid-derived suppressor cells, mesenchymal stromal cells, T-cells and various soluble factors plays a central role in immune regulation [166,167]. 
Data obtained by preclinical studies suggest that the immune escape of leukemia stem cells may be pursued by activation of the immune checkpoint pathways, and thus treatment strategies based on ICI therapy might be a promising option to eradicate MRD in patients who achieved CR after induction and consolidation therapy [168]. A phase II study (NCT02532231) was conducted in order to investigate the efficacy of nivolumab maintenance in AML patients at a high risk of relapse who achieved CR after induction and consolidation chemotherapy: 1-year OS rate was $86 \%$ and grade $3 / 4$ IRAEs was reported in 5 out of 14 patients [169].

Relapse after allo-HSCT is associated with a poor prognosis, and thus treatment strategies aimed at treating and preventing a relapse play a fundamental role in clinical practice [170-172]. One of the suggested mechanisms of relapse consists of the downregulation of patient-specific HLA haplotypes, which allows for immune escape from donor T-cells surveillance $[173,174]$. In a phase I clinical trial (NCT01822509), ipilimumab was tested in patients' hematologic malignancies who relapsed after allo-HSCT: in this study, 5 out of 28 patients ( 4 out of 12 AML patients) achieved a CR and with a median 1-year OS rate of $49 \%$ [175]. In this study, the safety of ipilimumab in the post-allo-HSCT setting was enlightened by the few cases (only 4 patients) of liver and gastrointestinal GVHD reported [175]. Another clinical trial (NCT00060372) was performed on 29 patients who relapsed after allo-HSCT or after donor lymphocytes infusion (DLI) (of which two patients had AML): this study reported an objective response in only three patients with lymphoid malignancies and in none of the AML patients [176]. Furthermore, a case series reported results obtained by three AML patients who relapsed after allo-HSCT and who were treated with nivolumab: one out of three patients achieved a durable CR, while disease stabilization was reached by another one [177].

While the stimulation of the graft-versus-leukemia (GvL) effect by ICB may be beneficial in prevention and treatment of relapse, there are a lot of concerns about the risk of an increased incidence and the severity of GvHD when this therapeutic strategy is adopted in the post-allo-HSCT setting. A fatal GvHD induced by the PD-1 blockade has been repeatedly reported in the post-allo-HSCT setting and seems to have a poor response to therapy with corticosteroids $[178,179]$. Additional studies to evaluate both the safety and the efficacy of ICI for the treatment of myeloid malignancies relapsed after allo-HSCT are warranted.

\section{Conclusions}

The above reported results obtained by MFC, RT-qPCR and NGS after induction/ consolidation chemotherapy and in the peri-transplant period provide convincing evidence that MRD status effectively predicts the risk of relapse and OS/DFS in AML patients, even after allo-HSCT. A progressive substitution of the morphology-based definition of CR with the MRD-based definition of CR will probably allow for an improvement of patients' clinical outcome. Indeed, MRD-based CR definition will allow us to reach a deeper definition of the remission status. Moreover, continuous development of more sensitive technologies for MRD analysis is required because $50 \%$ of patients who are MRD- still relapse [5]. Finally, a wider adoption of an MRD-based definition of CR will allow us to clarify the optimal timing for performing an MRD assay and whether MRD assessment after induction, consolidation and pre-allo-HSCT might have distinct prognostic relevance. More importantly, apart from its prognostic significance, MRD status may function as a guide for clinical hematologists to choose the most appropriate post-remission treatments. Furthermore, use of MRD as a surrogate endpoint for OS will allow for faster development of novel drugs. The second part of this review focused on the most promising targets of MRD-directed treatments. Currently, in AML management, use of BCL2 inhibitors combined with HMA is emerging as one of the most effective strategies for achieving MRD clearance. In FLT3-ITD+ patients, the results achieved by combining intensive chemotherapy with FLT3 inhibitors are so exciting that a post-transplant preemptive treatment with these inhibitors has been proposed. The inclusion of high-risk patients in these MRD-directed clinical trials is mandatory to increase 
our knowledge of how MRD can be employed to drive post-remission treatment strategies and improve our patients' clinical outcome.

Supplementary Materials: The following are available online at https://www.mdpi.com/article/10 .3390 / cancers13133170/s1, Table S1: Most relevant MRD studies in AML with molecular markers, Table S2: most relevant MRD studies in AML with MFC.

Author Contributions: P.B. and O.B. critically reviewed literature data and wrote the manuscript. Both authors have read and agreed to the published version of the manuscript.

Funding: This research received no external funding.

Conflicts of Interest: The authors declare no conflict of interest.

\section{Abbreviations}

allo-HSCT Allogeneic hematopoietic stem cell transplantation

BM bone marrow

cGvHD chronic graft-versus-host disease

CMC complete mutation clearance

$\mathrm{CR} \quad$ complete remission

$\mathrm{CRi} \quad$ complete response with incomplete hematological recovery

CIR cumulative incidence of relapse

DfN different from normal

ddPCR digital droplet PCR

DFS disease-free survival

DLI donor lymphocytes infusion

EFS event-free survival

GvL graft versus leukemia

GRFS GvHD relapse-free survival

Hh Hedgehog

HMA hypomethylating agents

ICB immune checkpoint blockade

ICI immune checkpoint inhibitors

IDH1/2 Isocitrate dehydrogenase $1 / 2$

LAIP leukemia-associated aberrant immunophenotypes

LIC leukemic initiating cells

LDAC low-dose Cytosine-Arabinoside

MUD matched unrelated donors

MRD measurable residual disease

mMUD mismatched unrelated donors

MFC multi-parameter flow cytometry

MC mutation clearance

MAC myelo-ablative conditioning

MDS myelodisplastic syndrome

NGS Next Generation Sequencing

NMA non-myelo-ablative conditioning

NRM non-relapse mortality

NPM1m NPM1 mutated

NPM1wt NPM1 wild-type

ORR overall-response rate

OS overall survival

PR partial response

PB peripheral blood

RIC reduced intensity conditioning

RR relapse rate

RFS relapse-free survival

RT-qPCR reverse quantitative polymerase chain reaction

SMO sonic hedgehog receptor smoothened

VAF variant allele frequencies 


\section{References}

1. Döhner, H.; Estey, E.; Grimwade, D.; Amadori, S.; Appelbaum, F.R.; Büchner, T.; Dombret, H.; Ebert, B.L.; Fenaux, P.; Larson, R.A.; et al. Diagnosis and management of AML in adults: 2017 ELN recommendations from an international expert panel. Blood 2017, 129, 424-447. [CrossRef]

2. Ossenkoppele, G.; Schuurhuis, G.J. MRD in AML: Does it already guide therapy decision-making? Hematology. Am. Soc. Hematology. Educ. Program. 2016, 2016, 356-365. [CrossRef] [PubMed]

3. Mayer, R.J.; Davis, R.B.; Schiffer, C.A.; Berg, D.T.; Powell, B.L.; Schulman, P.; Omura, G.A.; Moore, J.O.; McIntyre, O.R.; Frei, E. Intensive postremission chemotherapy in adults with acute myeloid leukemia. Cancer and Leukemia Group B. N. Engl. J. Med. 1994, 331, 896-903. [CrossRef] [PubMed]

4. Döhner, H.; Weisdorf, D.J.; Bloomfield, C.D. Acute Myeloid Leukemia. N. Engl. J. Med. 2015, 373, 1136-1152. [CrossRef] [PubMed]

5. Short, N.J.; Ravandi, F. How close are we to incorporating measurable residual disease into clinical practice for acute myeloid leukemia? Haematologica 2019, 104, 1532-1541. [CrossRef]

6. Walter, R.B.; Othus, M.; Burnett, A.K.; Löwenberg, B.; Kantarjian, H.M.; Ossenkoppele, G.J.; Hills, R.K.; Ravandi, F.; Pabst, T.; Evans, A.; et al. Resistance prediction in AML: Analysis of 4601 patients from MRC/NCRI, HOVON/SAKK, SWOG and MD Anderson Cancer Center. Leukemia 2015, 29, 312-320. [CrossRef]

7. Schuurhuis, G.J.; Heuser, M.; Freeman, S.; Béné, M.C.; Buccisano, F.; Cloos, J.; Grimwade, D.; Haferlach, T.; Hills, R.K.; Hourigan, C.S.; et al. Minimal/measurable residual disease in AML: A consensus document from the European LeukemiaNet MRD Working Party. Blood 2018, 131, 1275-1291. [CrossRef]

8. San Miguel, J.F.; Martínez, A.; Macedo, A.; Vidriales, M.B.; López-Berges, C.; González, M.; Caballero, D.; García-Marcos, M.A.; Ramos, F.; Fernández-Calvo, J.; et al. Immunophenotyping investigation of minimal residual disease is a useful approach for predicting relapse in acute myeloid leukemia patients. Blood 1997, 90, 2465-2470. [CrossRef]

9. Buccisano, F.; Maurillo, L.; Gattei, V.; Del Poeta, G.; Del Principe, M.I.; Cox, M.C.; Panetta, P.; Consalvo, M.I.; Mazzone, C.; Neri, B.; et al. The kinetics of reduction of minimal residual disease impacts on duration of response and survival of patients with acute myeloid leukemia. Leukemia 2006, 20, 1783-1789. [CrossRef]

10. Thol, F.; Gabdoulline, R.; Liebich, A.; Klement, P.; Schiller, J.; Kandziora, C.; Hambach, L.; Stadler, M.; Koenecke, C.; Flintrop, M.; et al. Measurable residual disease monitoring by NGS before allogeneic hematopoietic cell transplantation in AML. Blood 2018, 132, 1703-1713. [CrossRef]

11. Zeijlemaker, W.; Kelder, A.; Cloos, J.; Schuurhuis, G.J. Immunophenotypic Detection of Measurable Residual (Stem Cell) Disease Using LAIP Approach in Acute Myeloid Leukemia. Curr. Protoc. Cytom. 2019, 91, e66. [CrossRef]

12. Baer, M.R.; Stewart, C.C.; Dodge, R.K.; Leget, G.; Sulé, N.; Mrózek, K.; Schiffer, C.A.; Powell, B.L.; Kolitz, J.E.; Moore, J.O.; et al. High frequency of immunophenotype changes in acute myeloid leukemia at relapse: Implications for residual disease detection (Cancer and Leukemia Group B Study 8361). Blood 2001, 97, 3574-3580. [CrossRef] [PubMed]

13. Terwijn, M.; van Putten, W.L.; Kelder, A.; van der Velden, V.H.; Brooimans, R.A.; Pabst, T.; Maertens, J.; Boeckx, N.; de Greef, G.E.; Valk, P.J.; et al. High prognostic impact of flow cytometric minimal residual disease detection in acute myeloid leukemia: Data from the HOVON/SAKK AML 42A study. J. Clin. Oncol. Off. J. Am. Soc. Clin. Oncol. 2013, 31, 3889-3897. [CrossRef]

14. Lapidot, T.; Sirard, C.; Vormoor, J.; Murdoch, B.; Hoang, T.; Caceres-Cortes, J.; Minden, M.; Paterson, B.; Caligiuri, M.A.; Dick, J.E. A cell initiating human acute myeloid leukaemia after transplantation into SCID mice. Nature 1994, 367, 645-648. [CrossRef]

15. Shlush, L.I.; Mitchell, A.; Heisler, L.; Abelson, S.; Ng, S.W.K.; Trotman-Grant, A.; Medeiros, J.J.F.; Rao-Bhatia, A.; JaciwZurakowsky, I.; Marke, R.; et al. Tracing the origins of relapse in acute myeloid leukaemia to stem cells. Nature 2017, 547, 104-108. [CrossRef]

16. Ding, L.; Ley, T.J.; Larson, D.E.; Miller, C.A.; Koboldt, D.C.; Welch, J.S.; Ritchey, J.K.; Young, M.A.; Lamprecht, T.; McLellan, M.D.; et al. Clonal evolution in relapsed acute myeloid leukaemia revealed by whole-genome sequencing. Nature 2012, 481, 506-510. [CrossRef] [PubMed]

17. Bachas, C.; Schuurhuis, G.J.; Assaraf, Y.G.; Kwidama, Z.J.; Kelder, A.; Wouters, F.; Snel, A.N.; Kaspers, G.J.; Cloos, J. The role of minor subpopulations within the leukemic blast compartment of AML patients at initial diagnosis in the development of relapse. Leukemia 2012, 26, 1313-1320. [CrossRef] [PubMed]

18. Ottone, T.; Zaza, S.; Divona, M.; Hasan, S.K.; Lavorgna, S.; Laterza, S.; Cicconi, L.; Panetta, P.; Di Giandomenico, J.; Cittadini, M.; et al. Identification of emerging FLT3 ITD-positive clones during clinical remission and kinetics of disease relapse in acute myeloid leukaemia with mutated nucleophosmin. Br. J. Haematol. 2013, 161, 533-540. [CrossRef]

19. Walter, R.B.; Ofran, Y.; Wierzbowska, A.; Ravandi, F.; Hourigan, C.S.; Ngai, L.L.; Venditti, A.; Buccisano, F.; Ossenkoppele, G.J.; Roboz, G.J. Measurable residual disease as a biomarker in acute myeloid leukemia: Theoretical and practical considerations. Leukemia 2021, 35, 1529-1538. [CrossRef]

20. Freeman, S.D.; Virgo, P.; Couzens, S.; Grimwade, D.; Russell, N.; Hills, R.K.; Burnett, A.K. Prognostic relevance of treatment response measured by flow cytometric residual disease detection in older patients with acute myeloid leukemia. J. Clin. Oncol. Off. J. Am. Soc. Clin. Oncol. 2013, 31, 4123-4131. [CrossRef] [PubMed]

21. Ivey, A.; Hills, R.K.; Simpson, M.A.; Jovanovic, J.V.; Gilkes, A.; Grech, A.; Patel, Y.; Bhudia, N.; Farah, H.; Mason, J.; et al. Assessment of Minimal Residual Disease in Standard-Risk AML. N. Engl. J. Med. 2016, 374, 422-433. [CrossRef] 
22. Balsat, M.; Renneville, A.; Thomas, X.; de Botton, S.; Caillot, D.; Marceau, A.; Lemasle, E.; Marolleau, J.P.; Nibourel, O.; Berthon, C.; et al. Postinduction Minimal Residual Disease Predicts Outcome and Benefit From Allogeneic Stem Cell Transplantation in Acute Myeloid Leukemia With NPM1 Mutation: A Study by the Acute Leukemia French Association Group. J. Clin. Oncol. Off. J. Am. Soc. Clin. Oncol. 2017, 35, 185-193. [CrossRef]

23. Ravandi, F.; Jorgensen, J.; Borthakur, G.; Jabbour, E.; Kadia, T.; Pierce, S.; Brandt, M.; Wang, S.; Konoplev, S.; Wang, X.; et al. Persistence of minimal residual disease assessed by multiparameter flow cytometry is highly prognostic in younger patients with acute myeloid leukemia. Cancer 2017, 123, 426-435. [CrossRef]

24. Freeman, S.D.; Hills, R.K.; Virgo, P.; Khan, N.; Couzens, S.; Dillon, R.; Gilkes, A.; Upton, L.; Nielsen, O.J.; Cavenagh, J.D.; et al. Measurable Residual Disease at Induction Redefines Partial Response in Acute Myeloid Leukemia and Stratifies Outcomes in Patients at Standard Risk Without NPM1 Mutations. J. Clin. Oncol. Off. J. Am. Soc. Clin. Oncol. 2018, 36, 486-1497. [CrossRef]

25. Jongen-Lavrencic, M.; Grob, T.; Hanekamp, D.; Kavelaars, F.G.; Al Hinai, A.; Zeilemaker, A.; Erpelinck-Verschueren, C.A.J.; Gradowska, P.L.; Meijer, R.; Cloos, J.; et al. Molecular Minimal Residual Disease in Acute Myeloid Leukemia. N. Engl. J. Med. 2018, 378, 1189-1199. [CrossRef]

26. Czyz, A.; Nagler, A. The Role of Measurable Residual Disease (MRD) in Hematopoietic Stem Cell Transplantation for Hematological Malignancies Focusing on Acute Leukemia. Int. J. Mol. Sci. 2019, 20, 5362. [CrossRef] [PubMed]

27. Maurillo, L.; Buccisano, F.; Del Principe, M.I.; Del Poeta, G.; Spagnoli, A.; Panetta, P.; Ammatuna, E.; Neri, B.; Ottaviani, L.; Sarlo, C.; et al. Toward optimization of postremission therapy for residual disease-positive patients with acute myeloid leukemia. $J$. Clin. Oncol. Off. J. Am. Soc. Clin. Oncol. 2008, 26, 4944-4951. [CrossRef]

28. Roussel, X.; Daguindau, E.; Berceanu, A.; Desbrosses, Y.; Warda, W.; Neto da Rocha, M.; Trad, R.; Deconinck, E.; Deschamps, M.; Ferrand, C. Acute Myeloid Leukemia: From Biology to Clinical Practices Through Development and Pre-Clinical Therapeutics. Front. Oncol. 2020, 10, 599933. [CrossRef] [PubMed]

29. Staudt, D.; Murray, H.C.; McLachlan, T.; Alvaro, F.; Enjeti, A.K.; Verrills, N.M.; Dun, M.D. Targeting Oncogenic Signaling in Mutant FLT3 Acute Myeloid Leukemia: The Path to Least Resistance. Int. J. Mol. Sci. 2018, 19, 3198. [CrossRef] [PubMed]

30. Willekens, C.; Blanchet, O.; Renneville, A.; Cornillet-Lefebvre, P.; Pautas, C.; Guieze, R.; Ifrah, N.; Dombret, H.; Jourdan, E.; Preudhomme, C.; et al. Prospective long-term minimal residual disease monitoring using RQ-PCR in RUNX1-RUNX1T1-positive acute myeloid leukemia: Results of the French CBF-2006 trial. Haematologica 2016, 101, 328-335. [CrossRef] [PubMed]

31. Yin, J.A.; O'Brien, M.A.; Hills, R.K.; Daly, S.B.; Wheatley, K.; Burnett, A.K. Minimal residual disease monitoring by quantitative RT-PCR in core binding factor AML allows risk stratification and predicts relapse: Results of the United Kingdom MRC AML-15 trial. Blood 2012, 120, 2826-2835. [CrossRef]

32. Zhu, H.H.; Zhang, X.H.; Qin, Y.Z.; Liu, D.H.; Jiang, H.; Chen, H.; Jiang, Q.; Xu, L.P.; Lu, J.; Han, W.; et al. MRD-directed risk stratification treatment may improve outcomes of $\mathrm{t}(8 ; 21)$ AML in the first complete remission: Results from the AML05 multicenter trial. Blood 2013, 121, 4056-4062. [CrossRef]

33. Krönke, J.; Schlenk, R.F.; Jensen, K.O.; Tschürtz, F.; Corbacioglu, A.; Gaidzik, V.I.; Paschka, P.; Onken, S.; Eiwen, K.; Habdank, M.; et al. Monitoring of minimal residual disease in NPM1-mutated acute myeloid leukemia: A study from the German-Austrian acute myeloid leukemia study group. J. Clin. Oncol. 2011, 29, 2709-2716. [CrossRef]

34. Shayegi, N.; Kramer, M.; Bornhäuser, M.; Schaich, M.; Schetelig, J.; Platzbecker, U.; Röllig, C.; Heiderich, C.; Landt, O.; Ehninger, G.; et al. The level of residual disease based on mutant NPM1 is an independent prognostic factor for relapse and survival in AML. Blood 2013, 122, 83-92. [CrossRef]

35. Cilloni, D.; Renneville, A.; Hermitte, F.; Hills, R.K.; Daly, S.; Jovanovic, J.V.; Gottardi, E.; Fava, M.; Schnittger, S.; Weiss, T.; et al. Real-time quantitative polymerase chain reaction detection of minimal residual disease by standardized WT1 assay to enhance risk stratification in acute myeloid leukemia: A European LeukemiaNet study. J. Clin. Oncol. 2009, 27, 5195-5201. [CrossRef]

36. Nomdedéu, J.F.; Hoyos, M.; Carricondo, M.; Bussaglia, E.; Estivill, C.; Esteve, J.; Tormo, M.; Duarte, R.; Salamero, O.; de Llano, M.P.; et al. Bone marrow WT1 levels at diagnosis, post-induction and post-intensification in adult de novo AML. Leukemia 2013, 27, 2157-2164. [CrossRef]

37. Dillon, R.; Hills, R.; Freeman, S.; Potter, N.; Jovanovic, J.; Ivey, A.; Kanda, A.S.; Runglall, M.; Foot, N.; Valganon, M.; et al. Molecular MRD status and outcome after transplantation in NPM1-mutated AML. Blood 2020, 135, 680-688. [CrossRef]

38. Venditti, A.; Buccisano, F.; Del Poeta, G.; Maurillo, L.; Tamburini, A.; Cox, C.; Battaglia, A.; Catalano, G.; Del Moro, B.; Cudillo, L.; et al. Level of minimal residual disease after consolidation therapy predicts outcome in acute myeloid leukemia. Blood 2000, 96, 3948-3952. [CrossRef]

39. San Miguel, J.F.; Vidriales, M.B.; López-Berges, C.; Díaz-Mediavilla, J.; Gutiérrez, N.; Cañizo, C.; Ramos, F.; Calmuntia, M.J.; Pérez, J.J.; González, M.; et al. Early immunophenotypical evaluation of minimal residual disease in acute myeloid leukemia identifies different patient risk groups and may contribute to postinduction treatment stratification. Blood 2001, 98, 1746-1751. [CrossRef] [PubMed]

40. Sievers, E.L.; Lange, B.J.; Alonzo, T.A.; Gerbing, R.B.; Bernstein, I.D.; Smith, F.O.; Arceci, R.J.; Woods, W.G.; Loken, M.R. Immunophenotypic evidence of leukemia after induction therapy predicts relapse: Results from a prospective Children's Cancer Group study of 252 patients with acute myeloid leukemia. Blood 2003, 101, 3398-3406. [CrossRef]

41. Kern, W.; Voskova, D.; Schoch, C.; Schnittger, S.; Hiddemann, W.; Haferlach, T. Prognostic impact of early response to induction therapy as assessed by multiparameter flow cytometry in acute myeloid leukemia. Haematologica 2004, 89, 528-540. 
42. Kern, W.; Voskova, D.; Schoch, C.; Hiddemann, W.; Schnittger, S.; Haferlach, T. Determination of relapse risk based on assessment of minimal residual disease during complete remission by multiparameter flow cytometry in unselected patients with acute myeloid leukemia. Blood 2004, 104, 3078-3085. [CrossRef]

43. Langebrake, C.; Creutzig, U.; Dworzak, M.; Hrusak, O.; Mejstrikova, E.; Griesinger, F.; Zimmermann, M.; Reinhardt, D.; MRDAML-BFM Study Group. Residual disease monitoring in childhood acute myeloid leukemia by multiparameter flow cytometry: The MRD-AML-BFM Study Group. J. Clin. Oncol. 2006, 24, 3686-3692. [CrossRef]

44. Al-Mawali, A.; Gillis, D.; Lewis, I. The role of multiparameter flow cytometry for detection of minimal residual disease in acute myeloid leukemia. Am. J. Clin. Pathol. 2009, 131, 16-26. [CrossRef] [PubMed]

45. Van der Velden, V.H.; van der Sluijs-Geling, A.; Gibson, B.E.; te Marvelde, J.G.; Hoogeveen, P.G.; Hop, W.C.; Wheatley, K.; Bierings, M.B.; Schuurhuis, G.J.; de Graaf, S.S.; et al. Clinical significance of flowcytometric minimal residual disease detection in pediatric acute myeloid leukemia patients treated according to the DCOG ANLL97/MRC AML12 protocol. Leukemia 2010, 24, 1599-1606. [CrossRef] [PubMed]

46. Loken, M.R.; Alonzo, T.A.; Pardo, L.; Gerbing, R.B.; Raimondi, S.C.; Hirsch, B.A.; Ho, P.A.; Franklin, J.; Cooper, T.M.; Gamis, A.S.; et al. Residual disease detected by multidimensional flow cytometry signifies high relapse risk in patients with de novo acute myeloid leukemia: A report from Children's Oncology Group. Blood 2012, 120, 1581-1588. [CrossRef]

47. Inaba, H.; Coustan-Smith, E.; Cao, X.; Pounds, S.B.; Shurtleff, S.A.; Wang, K.Y.; Raimondi, S.C.; Onciu, M.; Jacobsen, J.; Ribeiro, R.C.; et al. Comparative analysis of different approaches to measure treatment response in acute myeloid leukemia. J. Clin. Oncol. 2012, 30, 3625-3632. [CrossRef]

48. Walter, R.B.; Buckley, S.A.; Pagel, J.M.; Wood, B.L.; Storer, B.E.; Sandmaier, B.M.; Fang, M.; Gyurkocza, B.; Delaney, C.; Radich, J.P.; et al. Significance of minimal residual disease before myeloablative allogeneic hematopoietic cell transplantation for AML in first and second complete remission. Blood 2013, 122, 1813-1821. [CrossRef]

49. Buccisano, F.; Maurillo, L.; Piciocchi, A.; Del Principe, M.I.; Sarlo, C.; Cefalo, M.; Ditto, C.; Di Veroli, A.; De Santis, G.; Irno Consalvo, M.; et al. Minimal residual disease negativity in elderly patients with acute myeloid leukemia may indicate different postremission strategies than in younger patients. Ann. Hematol. 2015, 94, 1319-1326. [CrossRef]

50. Köhnke, T.; Sauter, D.; Ringel, K.; Hoster, E.; Laubender, R.P.; Hubmann, M.; Bohlander, S.K.; Kakadia, P.M.; Schneider, S.; Dufour, A.; et al. Early assessment of minimal residual disease in AML by flow cytometry during aplasia identifies patients at increased risk of relapse. Leukemia 2015, 29, 377-386. [CrossRef]

51. Zhou, Y.; Othus, M.; Araki, D.; Wood, B.L.; Radich, J.P.; Halpern, A.B.; Mielcarek, M.; Estey, E.H.; Appelbaum, F.R.; Walter, R.B. Pre- and post-transplant quantification of measurable ('minimal') residual disease via multiparameter flow cytometry in adult acute myeloid leukemia. Leukemia 2016, 30, 1813-1821. [CrossRef]

52. Araki, D.; Wood, B.L.; Othus, M.; Radich, J.P.; Halpern, A.B.; Zhou, Y.; Mielcarek, M.; Estey, E.H.; Appelbaum, F.R.; Walter, R.B. Allogeneic Hematopoietic Cell Transplantation for Acute Myeloid Leukemia: Time to Move Toward a Minimal Residual Disease-Based Definition of Complete Remission? J. Clin. Oncol. Off. J. Am. Soc. Clin. Oncol. 2016, 34, 1813-1821. [CrossRef]

53. Tierens, A.; Bjørklund, E.; Siitonen, S.; Marquart, H.V.; Wulff-Juergensen, G.; Pelliniemi, T.T.; Forestier, E.; Hasle, H.; Jahnukainen, K.; Lausen, B.; et al. Residual disease detected by flow cytometry is an independent predictor of survival in childhood acute myeloid leukaemia; results of the NOPHO-AML 2004 study. Br. J. Haematol. 2016, 174, 600-609. [CrossRef]

54. Rubnitz, J.E.; Inaba, H.; Dahl, G.; Ribeiro, R.C.; Bowman, W.P.; Taub, J.; Pounds, S.; Razzouk, B.I.; Lacayo, N.J.; Cao, X.; et al. Minimal residual disease-directed therapy for childhood acute myeloid leukaemia: Results of the AML02 multicentre trial. Lancet Oncol. 2010, 11, 543-552. [CrossRef]

55. Zeijlemaker, W.; Grob, T.; Meijer, R.; Hanekamp, D.; Kelder, A.; Carbaat-Ham, J.C.; Oussoren-Brockhoff, Y.J.M.; Snel, A.N.; Veldhuizen, D.; Scholten, W.J.; et al. CD34+CD38- leukemic stem cell frequency to predict outcome in acute myeloid leukemia. Leukemia 2019, 33, 1102-1112. [CrossRef] [PubMed]

56. Venditti, A.; Piciocchi, A.; Candoni, A.; Melillo, L.; Calafiore, V.; Cairoli, R.; de Fabritiis, P.; Storti, G.; Salutari, P.; Lanza, F.; et al. GIMEMA AML1310 trial of risk-adapted, MRD-directed therapy for young adults with newly diagnosed acute myeloid leukemia. Blood 2019, 134, 1813-1821. [CrossRef]

57. Short, N.J.; Rafei, H.; Daver, N.; Hwang, H.; Ning, J.; Jorgensen, J.L.; Kadia, T.M.; DiNardo, C.D.; Wang, S.A.; Jabbour, E.; et al. Prognostic impact of complete remission with MRD negativity in patients with relapsed or refractory AML. Blood Adv. 2020, 4, 1813-1821. [CrossRef] [PubMed]

58. Coltoff, A.; Houldsworth, J.; Keyzner, A.; Renteria, A.S.; Mascarenhas, J. Role of minimal residual disease in the management of acute myeloid leukemia-a case-based discussion. Ann. Hematol. 2018, 97, 377-386. [CrossRef] [PubMed]

59. Buonamici, S.; Ottaviani, E.; Testoni, N.; Montefusco, V.; Visani, G.; Bonifazi, F.; Amabile, M.; Terragna, C.; Ruggeri, D.; Piccaluga, P.P.; et al. Real-time quantitation of minimal residual disease in inv(16)-positive acute myeloid leukemia may indicate risk for clinical relapse and may identify patients in a curable state. Blood 2002, 99, 377-386. [CrossRef] [PubMed]

60. Guerrasio, A.; Pilatrino, C.; De Micheli, D.; Cilloni, D.; Serra, A.; Gottardi, E.; Parziale, A.; Marmont, F.; Diverio, D.; Divona, M.; et al. Assessment of minimal residual disease (MRD) in CBFbeta/MYH11-positive acute myeloid leukemias by qualitative and quantitative RT-PCR amplification of fusion transcripts. Leukemia 2002, 16, 377-386. [CrossRef]

61. Gorello, P.; Cazzaniga, G.; Alberti, F.; Dell'Oro, M.G.; Gottardi, E.; Specchia, G.; Roti, G.; Rosati, R.; Martelli, M.F.; Diverio, D.; et al. Quantitative assessment of minimal residual disease in acute myeloid leukemia carrying nucleophosmin (NPM1) gene mutations. Leukemia 2006, 20, 1456-1464. [CrossRef] 
62. Jourdan, E.; Boissel, N.; Chevret, S.; Delabesse, E.; Renneville, A.; Cornillet, P.; Blanchet, O.; Cayuela, J.M.; Recher, C.; Raffoux, E.; et al. Prospective evaluation of gene mutations and minimal residual disease in patients with core binding factor acute myeloid leukemia. Blood 2013, 121, 1456-1464. [CrossRef] [PubMed]

63. Burnett, A.K.; Hills, R.K.; Milligan, D.; Kjeldsen, L.; Kell, J.; Russell, N.H.; Yin, J.A.; Hunter, A.; Goldstone, A.H.; Wheatley, K. Identification of patients with acute myeloblastic leukemia who benefit from the addition of gemtuzumab ozogamicin: Results of the MRC AML15 trial. J. Clin. Oncol. Off. J. Am. Soc. Clin. Oncol. 2011, 29, 1456-1464. [CrossRef] [PubMed]

64. Cornelissen, J.J.; Gratwohl, A.; Schlenk, R.F.; Sierra, J.; Bornhäuser, M.; Juliusson, G.; Råcil, Z.; Rowe, J.M.; Russell, N.; Mohty, M.; et al. The European LeukemiaNet AML Working Party consensus statement on allogeneic HSCT for patients with AML in remission: An integrated-risk adapted approach. Nat. Reviews. Clin. Oncol. 2012, 9, 329-336. [CrossRef]

65. Schlenk, R.F.; Kayser, S.; Bullinger, L.; Kobbe, G.; Casper, J.; Ringhoffer, M.; Held, G.; Brossart, P.; Lübbert, M.; Salih, H.R.; et al. Differential impact of allelic ratio and insertion site in FLT3-ITD-positive AML with respect to allogeneic transplantation. Blood 2014, 124, 329-336. [CrossRef] [PubMed]

66. Sakaguchi, M.; Yamaguchi, H.; Najima, Y.; Usuki, K.; Ueki, T.; Oh, I.; Mori, S.; Kawata, E.; Uoshima, N.; Kobayashi, Y.; et al. Prognostic impact of low allelic ratio FLT3-ITD and NPM1 mutation in acute myeloid leukemia. Blood Adv. 2018, 2, $2744-2754$. [CrossRef]

67. Walter, R.B.; Gooley, T.A.; Wood, B.L.; Milano, F.; Fang, M.; Sorror, M.L.; Estey, E.H.; Salter, A.I.; Lansverk, E.; Chien, J.W.; et al. Impact of pretransplantation minimal residual disease, as detected by multiparametric flow cytometry, on outcome of myeloablative hematopoietic cell transplantation for acute myeloid leukemia. J. Clin. Oncol. Off. J. Am. Soc. Clin. Oncol. 2011, 29, 329-336. [CrossRef]

68. Buccisano, F.; Maurillo, L.; Piciocchi, A.; Del Principe, M.I.; Picardi, A.; Cerretti, R.; Cudillo, L.; De Angelis, G.; Sarlo, C.; Cefalo, M.; et al. Pre-transplant persistence of minimal residual disease does not contraindicate allogeneic stem cell transplantation for adult patients with acute myeloid leukemia. Bone Marrow Transplant. 2017, 52, 329-336. [CrossRef]

69. Klco, J.M.; Miller, C.A.; Griffith, M.; Petti, A.; Spencer, D.H.; Ketkar-Kulkarni, S.; Wartman, L.D.; Christopher, M.; Lamprecht, T.L.; Helton, N.M.; et al. Association Between Mutation Clearance After Induction Therapy and Outcomes in Acute Myeloid Leukemia. JAMA 2015, 314, 935-945. [CrossRef]

70. Morita, K.; Kantarjian, H.M.; Wang, F.; Yan, Y.; Bueso-Ramos, C.; Sasaki, K.; Issa, G.C.; Wang, S.; Jorgensen, J.; Song, X.; et al. Clearance of Somatic Mutations at Remission and the Risk of Relapse in Acute Myeloid Leukemia. J. Clin. Oncol. Off. J. Am. Soc. Clin. Oncol. 2018, 36, 1788-1797. [CrossRef]

71. Versluis, J.; Kalin, B.; Zeijlemaker, W.; Passweg, J.; Graux, C.; Manz, M.G.; Vekemans, M.; Biemond, B.J.; Legdeur, M.J.C.; van Marwijk Kooy, M.; et al. Graft-Versus-Leukemia Effect of Allogeneic Stem-Cell Transplantation and Minimal Residual Disease in Patients With Acute Myeloid Leukemia in First Complete Remission. JCO Precis. Oncol. 2017, 2017, 1-13. [CrossRef]

72. Buckley, S.A.; Wood, B.L.; Othus, M.; Hourigan, C.S.; Ustun, C.; Linden, M.A.; DeFor, T.E.; Malagola, M.; Anthias, C.; Valkova, V.; et al. Minimal residual disease prior to allogeneic hematopoietic cell transplantation in acute myeloid leukemia: A meta-analysis Haematologica 2017, 102, 865-873. [CrossRef]

73. Oran, B.; Jorgensen, J.L.; Marin, D.; Wang, S.; Ahmed, S.; Alousi, A.M.; Andersson, B.S.; Bashir, Q.; Bassett, R.; Lyons, G.; et al. Pre-transplantation minimal residual disease with cytogenetic and molecular diagnostic features improves risk stratification in acute myeloid leukemia. Haematologica 2017, 102, 110-117. [CrossRef]

74. Morsink, L.M.; Othus, M.; Bezerra, E.D.; Wood, B.L.; Fang, M.; Sandmaier, B.M.; Mielcarek, M.; Schoch, G.; Storb, R.; Deeg, H.J.; et al. Impact of pretransplant measurable residual disease on the outcome of allogeneic hematopoietic cell transplantation in adult monosomal karyotype AML. Leukemia 2020, 34, 1577-1587. [CrossRef]

75. Shimoni, A.; Hardan, I.; Shem-Tov, N.; Yeshurun, M.; Yerushalmi, R.; Avigdor, A.; Ben-Bassat, I.; Nagler, A. Allogeneic hematopoietic stem-cell transplantation in AML and MDS using myeloablative versus reduced-intensity conditioning: The role of dose intensity. Leukemia 2006, 20, 322-328. [CrossRef]

76. Alyea, E.P.; Kim, H.T.; Ho, V.; Cutler, C.; DeAngelo, D.J.; Stone, R.; Ritz, J.; Antin, J.H.; Soiffer, R.J. Impact of conditioning regimen intensity on outcome of allogeneic hematopoietic cell transplantation for advanced acute myelogenous leukemia and myelodysplastic syndrome. Biol. Blood Marrow Transplant. J. Am. Soc. Blood Marrow Transplant. 2006, 12, 1047-1055. [CrossRef]

77. Bornhäuser, M.; Kienast, J.; Trenschel, R.; Burchert, A.; Hegenbart, U.; Stadler, M.; Baurmann, H.; Schäfer-Eckart, K.; Holler, E.; Kröger, N.; et al. Reduced-intensity conditioning versus standard conditioning before allogeneic haemopoietic cell transplantation in patients with acute myeloid leukaemia in first complete remission: A prospective, open-label randomised phase 3 trial. Lancet Oncol. 2012, 13, 1035-1044. [CrossRef]

78. Passweg, J.R.; Labopin, M.; Cornelissen, J.; Volin, L.; Socié, G.; Huynh, A.; Tabrizi, R.; Wu, D.; Craddock, C.; Schaap, N.; et al. Conditioning intensity in middle-aged patients with AML in first CR: No advantage for myeloablative regimens irrespective of the risk group-an observational analysis by the Acute Leukemia Working Party of the EBMT. Bone Marrow Transplant. 2015, 50, 1063-1068. [CrossRef]

79. Walter, R.B.; Gyurkocza, B.; Storer, B.E.; Godwin, C.D.; Pagel, J.M.; Buckley, S.A.; Sorror, M.L.; Wood, B.L.; Storb, R.; Appelbaum, F.R.; et al. Comparison of minimal residual disease as outcome predictor for AML patients in first complete remission undergoing myeloablative or nonmyeloablative allogeneic hematopoietic cell transplantation. Leukemia 2015, 29, 137-144. [CrossRef] 
80. Ustun, C.; Courville, E.L.; DeFor, T.; Dolan, M.; Randall, N.; Yohe, S.; Bejanyan, N.; Warlick, E.; Brunstein, C.; Weisdorf, D.J.; et al. Myeloablative, but not Reduced-Intensity, Conditioning Overcomes the Negative Effect of Flow-Cytometric Evidence of Leukemia in Acute Myeloid Leukemia. Biol. Blood Marrow Transplant. J. Am. Soc. Blood Marrow Transplant. 2016, $22,669-675$. [CrossRef]

81. Scott, B.L.; Pasquini, M.C.; Logan, B.R.; Wu, J.; Devine, S.M.; Porter, D.L.; Maziarz, R.T.; Warlick, E.D.; Fernandez, H.F.; Alyea, E.P.; et al. Myeloablative Versus Reduced-Intensity Hematopoietic Cell Transplantation for Acute Myeloid Leukemia and Myelodysplastic Syndromes. J. Clin. Oncol. Off. J. Am. Soc. Clin. Oncol. 2017, 35, 1154-1161. [CrossRef]

82. Gilleece, M.H.; Labopin, M.; Yakoub-Agha, I.; Volin, L.; Socié, G.; Ljungman, P.; Huynh, A.; Deconinck, E.; Wu, D.; Bourhis, J.H.; et al. Measurable residual disease, conditioning regimen intensity, and age predict outcome of allogeneic hematopoietic cell transplantation for acute myeloid leukemia in first remission: A registry analysis of 2292 patients by the Acute Leukemia Working Party European Society of Blood and Marrow Transplantation. Am. J. Hematol. 2018, 93, 1142-1152. [CrossRef]

83. Hourigan, C.S.; Dillon, L.W.; Gui, G.; Logan, B.R.; Fei, M.; Ghannam, J.; Li, Y.; Licon, A.; Alyea, E.P.; Bashey, A.; et al. Impact of Conditioning Intensity of Allogeneic Transplantation for Acute Myeloid Leukemia With Genomic Evidence of Residual Disease. J. Clin. Oncol. Off. J. Am. Soc. Clin. Oncol. 2020, 38, 1273-1283. [CrossRef]

84. Morsink, L.M.; Sandmaier, B.M.; Othus, M.; Palmieri, R.; Granot, N.; Bezerra, E.D.; Wood, B.L.; Mielcarek, M.; Schoch, G.; Davis, C.; et al. Conditioning Intensity, Pre-Transplant Flow Cytometric Measurable Residual Disease, and Outcome in Adults with Acute Myeloid Leukemia Undergoing Allogeneic Hematopoietic Cell Transplantation. Cancers 2020, 12, 2339. [CrossRef]

85. Gilleece, M.H.; Labopin, M.; Savani, B.N.; Yakoub-Agha, I.; Socié, G.; Gedde-Dahl, T.; Blaise, D.; Byrne, J.L.; Craddock, C.; Cornelissen, J.J.; et al. Allogeneic haemopoietic transplantation for acute myeloid leukaemia in second complete remission: A registry report by the Acute Leukaemia Working Party of the EBMT. Leukemia 2020, 34, 87-99. [CrossRef]

86. Malard, F.; Labopin, M.; Stuhler, G.; Bittenbring, J.; Ganser, A.; Tischer, J.; Michallet, M.; Kröger, N.; Schmid, C.; Huynh, A.; et al. Sequential Intensified Conditioning Regimen Allogeneic Hematopoietic Stem Cell Transplantation in Adult Patients with Intermediate- or High-Risk Acute Myeloid Leukemia in Complete Remission: A Study from the Acute Leukemia Working Party of the European Group for Blood and Marrow Transplantation. Biol. Blood Marrow Transplant. J. Am. Soc. Blood Marrow Transplant. 2017, 23, 278-284. [CrossRef]

87. Mohty, M.; Malard, F.; Blaise, D.; Milpied, N.; Socié, G.; Huynh, A.; Reman, O.; Yakoub-Agha, I.; Furst, S.; Guillaume, T.; et al. Sequential regimen of clofarabine, cytosine arabinoside and reduced-intensity conditioned transplantation for primary refractory acute myeloid leukemia. Haematologica 2017, 102, 184-191. [CrossRef]

88. Le Bourgeois, A.; Labopin, M.; Marçais, A.; de Latour, R.P.; Blaise, D.; Chantepie, S.; N'Guyen, S.; Maillard, N.; Forcade, E.; Yakoub-Agha, I.; et al. Sequential allogeneic hematopoietic stem cell transplantation for active refractory/relapsed myeloid malignancies: Results of a reduced-intensity conditioning preceded by clofarabine and cytosine arabinoside, a retrospective study on behalf of the SFGM-TC. Ann. Hematol. 2020, 99, 1855-1862. [CrossRef]

89. Milano, F.; Gooley, T.; Wood, B.; Woolfrey, A.; Flowers, M.E.; Doney, K.; Witherspoon, R.; Mielcarek, M.; Deeg, J.H.; Sorror, M.; et al. Cord-Blood Transplantation in Patients with Minimal Residual Disease. N. Engl. J. Med. 2016, 375, 944-953. [CrossRef]

90. Cahn, J.Y.; Labopin, M.; Sierra, J.; Blaise, D.; Reiffers, J.; Ferrant, A.; Bergmann, L.; Visani, G.; Cornelissen, J.; De Witte, T.; et al. No impact of high-dose cytarabine on the outcome of patients transplanted for acute myeloblastic leukaemia in first remission. Acute Leukaemia Working Party of the European Group for Blood and Marrow Transplantation (EBMT). Br. J. Haematol. 2000, 110, 308-314. [CrossRef]

91. Tallman, M.S.; Rowlings, P.A.; Milone, G.; Zhang, M.J.; Perez, W.S.; Weisdorf, D.; Keating, A.; Gale, R.P.; Geller, R.B.; Laughlin, M.J.; et al. Effect of postremission chemotherapy before human leukocyte antigen-identical sibling transplantation for acute myelogenous leukemia in first complete remission. Blood 2000, 96, 1254-1258.

92. Warlick, E.D.; Paulson, K.; Brazauskas, R.; Zhong, X.; Miller, A.M.; Camitta, B.M.; George, B.; Savani, B.N.; Ustun, C.; Marks, D.I.; et al. Effect of postremission therapy before reduced-intensity conditioning allogeneic transplantation for acute myeloid leukemia in first complete remission. Biol. Blood Marrow Transplant. J. Am. Soc. Blood Marrow Transplant. 2014, 20, 202-208. [CrossRef] [PubMed]

93. Yeshurun, M.; Labopin, M.; Blaise, D.; Cornelissen, J.J.; Sengeloev, H.; Vindelov, L.; Kuball, J.; Chevallier, P.; Craddock, C.; Socie, G.; et al. Impact of postremission consolidation chemotherapy on outcome after reduced-intensity conditioning allogeneic stem cell transplantation for patients with acute myeloid leukemia in first complete remission: A report from the Acute Leukemia Working Party of the European Group for Blood and Marrow Transplantation. Cancer 2014, 120, 855-863. [CrossRef]

94. Antar, A.I.; Otrock, Z.K.; Jabbour, E.; Mohty, M.; Bazarbachi, A. FLT3 inhibitors in acute myeloid leukemia: Ten frequently asked questions. Leukemia 2020, 34, 682-696. [CrossRef] [PubMed]

95. Metzelder, S.K.; Schroeder, T.; Lübbert, M.; Ditschkowski, M.; Götze, K.; Scholl, S.; Meyer, R.G.; Dreger, P.; Basara, N.; Fey, M.F.; et al. Long-term survival of sorafenib-treated FLT3-ITD-positive acute myeloid leukaemia patients relapsing after allogeneic stem cell transplantation. Eur. J. Cancer 2017, 86, 233-239. [CrossRef] [PubMed]

96. Mathew, N.R.; Baumgartner, F.; Braun, L.; O'Sullivan, D.; Thomas, S.; Waterhouse, M.; Müller, T.A.; Hanke, K.; Taromi, S.; Apostolova, P.; et al. Sorafenib promotes graft-versus-leukemia activity in mice and humans through IL-15 production in FLT3-ITD-mutant leukemia cells. Nat. Med. 2018, 24, 282-291. [CrossRef] [PubMed] 
97. Lange, A.; Jaskula, E.; Lange, J.; Dworacki, G.; Nowak, D.; Simiczyjew, A.; Mordak-Domagala, M.; Sedzimirska, M. The sorafenib anti-relapse effect after alloHSCT is associated with heightened alloreactivity and accumulation of CD8+PD-1+ (CD279+) lymphocytes in marrow. PLOS ONE 2018, 13, e0190525. [CrossRef]

98. Cortes, J.E.; Kantarjian, H.; Foran, J.M.; Ghirdaladze, D.; Zodelava, M.; Borthakur, G.; Gammon, G.; Trone, D.; Armstrong, R.C.; James, J.; et al. Phase I study of quizartinib administered daily to patients with relapsed or refractory acute myeloid leukemia irrespective of FMS-like tyrosine kinase 3-internal tandem duplication status. J. Clin. Oncol. Off. J. Am. Soc. Clin. Oncol. 2013, 31, 3681-3687. [CrossRef]

99. Cortes, J.; Perl, A.E.; Döhner, H.; Kantarjian, H.; Martinelli, G.; Kovacsovics, T.; Rousselot, P.; Steffen, B.; Dombret, H.; Estey, E.; et al. Quizartinib, an FLT3 inhibitor, as monotherapy in patients with relapsed or refractory acute myeloid leukaemia: An open-label, multicentre, single-arm, phase 2 trial. Lancet Oncol. 2018, 19, 889-903. [CrossRef]

100. Cortes, J.E.; Khaled, S.; Martinelli, G.; Perl, A.E.; Ganguly, S.; Russell, N.; Krämer, A.; Dombret, H.; Hogge, D.; Jonas, B.A.; et al. Quizartinib versus salvage chemotherapy in relapsed or refractory FLT3-ITD acute myeloid leukaemia (QuANTUM-R): A multicentre, randomised, controlled, open-label, phase 3 trial. Lancet Oncol. 2019, 20, 984-997. [CrossRef]

101. Perl, A.E.; Altman, J.K.; Cortes, J.; Smith, C.; Litzow, M.; Baer, M.R.; Claxton, D.; Erba, H.P.; Gill, S.; Goldberg, S.; et al. Selective inhibition of FLT3 by gilteritinib in relapsed or refractory acute myeloid leukaemia: A multicentre, first-in-human, open-label, phase 1-2 study. Lancet Oncol. 2017, 18, 1061-1075. [CrossRef]

102. Perl, A.E.; Martinelli, G.; Cortes, J.E.; Neubauer, A.; Berman, E.; Paolini, S.; Montesinos, P.; Baer, M.R.; Larson, R.A.; Ustun, C.; et al. Gilteritinib or Chemotherapy for Relapsed or Refractory FLT3-Mutated AML. N. Engl. J. Med. 2019, 381, 1728-1740. [CrossRef]

103. Stone, R.M.; Mandrekar, S.J.; Sanford, B.L.; Laumann, K.; Geyer, S.; Bloomfield, C.D.; Thiede, C.; Prior, T.W.; Döhner, K.; Marcucci, G.; et al. Midostaurin plus Chemotherapy for Acute Myeloid Leukemia with a FLT3 Mutation. N. Engl. J. Med. 2017, 377, 454-464. [CrossRef]

104. Schlenk, R.F.; Weber, D.; Fiedler, W.; Salih, H.R.; Wulf, G.; Salwender, H.; Schroeder, T.; Kindler, T.; Lübbert, M.; Wolf, D.; et al. Midostaurin added to chemotherapy and continued single-agent maintenance therapy in acute myeloid leukemia with FLT3-ITD. Blood 2019, 133, 840-851. [CrossRef]

105. Wang, E.S.; Tallman, M.S.; Stone, R.M.; Walter, R.B.; Karanes, C.; Jain, V.; Collins, R.H. Low Relapse Rate in Younger Patients $\leq 60$ Years Old with Newly Diagnosed FLT3-Mutated Acute Myeloid Leukemia (AML) Treated with Crenolanib and Cytarabine/Anthracycline Chemotherapy. Blood 2017, 130, 566. [CrossRef]

106. Altman, J.K.; Foran, J.M.; Pratz, K.W.; Trone, D.; Cortes, J.E.; Tallman, M.S. Phase 1 study of quizartinib in combination with induction and consolidation chemotherapy in patients with newly diagnosed acute myeloid leukemia. Am. J. Hematol. 2018, 93, 213-221. [CrossRef]

107. Pratz, K.; Cherry, M.; Altman, J.; Cooper, B.; Cruz, J.C.; Jurcic, J.; Levis, M.; Lin, T.; Perl, A.; Podoltsev, N.; et al. Updated results from a phase 1 study of gilteritinib in combination with induction and consolidation chemotherapy in patients with newly diagnosed AML. Blood 2018, 132 (Suppl. S1), 564. [CrossRef]

108. Chen, Y.B.; Li, S.; Lane, A.A.; Connolly, C.; Del Rio, C.; Valles, B.; Curtis, M.; Ballen, K.; Cutler, C.; Dey, B.R.; et al. Phase I trial of maintenance sorafenib after allogeneic hematopoietic stem cell transplantation for fms-like tyrosine kinase 3 internal tandem duplication acute myeloid leukemia. Biol. Blood Marrow Transplant. J. Am. Soc. Blood Marrow Transplant. 2014, 20, $2042-2048$. [CrossRef]

109. Brunner, A.M.; Li, S.; Fathi, A.T.; Wadleigh, M.; Ho, V.T.; Collier, K.; Connolly, C.; Ballen, K.K.; Cutler, C.S.; Dey, B.R.; et al. Haematopoietic cell transplantation with and without sorafenib maintenance for patients with FLT3-ITD acute myeloid leukaemia in first complete remission. Br. J. Haematol. 2016, 175, 496-504. [CrossRef]

110. Burchert, A.; Bug, G.; Fritz, L.V.; Finke, J.; Stelljes, M.; Röllig, C.; Wollmer, E.; Wäsch, R.; Bornhäuser, M.; Berg, T.; et al. Sorafenib Maintenance After Allogeneic Hematopoietic Stem Cell Transplantation for Acute Myeloid Leukemia With FLT3-Internal Tandem Duplication Mutation (SORMAIN). J. Clin. Oncol. Off. J. Am. Soc. Clin. Oncol. 2020, 38, JCO1903345. [CrossRef]

111. Bazarbachi, A.; Labopin, M.; Battipaglia, G.; Djabali, A.; Forcade, E.; Arcese, W.; Socié, G.; Blaise, D.; Halter, J.; Gerull, S.; et al Allogeneic Stem Cell Transplantation for FLT3-Mutated Acute Myeloid Leukemia: In vivo T-Cell Depletion and Posttransplant sorafenib Maintenance Improve Survival. A Retrospective Acute Leukemia Working Party-European Society for Blood and Marrow Transplant Study. Clin. Hematol. Int. 2019, 1, 58-74.

112. Levis, M.J.; Hamadani, M.; Logan, B.; Rosales, M.; Perl, A.E.; Devine, S.M.; Bahceci, E.; Chen, Y.A. A phase 3, trial of gilteritinib, as maintenance therapy after allogeneic hematopoietic stem cell transplantation in patients with FLT3-ITD+ AML. J. Clin. Oncol. 2018, 36, TPS7075. [CrossRef]

113. DiNardo, C.D.; Stein, E.M.; de Botton, S.; Roboz, G.J.; Altman, J.K.; Mims, A.S.; Swords, R.; Collins, R.H.; Mannis, G.N.; Pollyea, D.A.; et al. Durable Remissions with ivosidenib in IDH1-Mutated Relapsed or Refractory AML. N. Engl. J. Med. 2018, 378, 2386-2398. [CrossRef]

114. Roboz, G.J.; DiNardo, C.D.; Stein, E.M.; de Botton, S.; Mims, A.S.; Prince, G.T.; Altman, J.K.; Arellano, M.L.; Donnellan, W.; Erba, H.P.; et al. Ivosidenib induces deep durable remissions in patients with newly diagnosed IDH1-mutant acute myeloid leukemia. Blood 2020, 135, 463-471. [CrossRef] [PubMed]

115. Stein, E.M.; DiNardo, C.D.; Pollyea, D.A.; Fathi, A.T.; Roboz, G.J.; Altman, J.K.; Stone, R.M.; DeAngelo, D.J.; Levine, R.L.; Flinn, I.W.; et al. Enasidenib in mutant IDH2 relapsed or refractory acute myeloid leukemia. Blood 2017, 130, 722-731. [CrossRef] 
116. Stein, E.M.; DiNardo, C.D.; Fathi, A.T.; Pollyea, D.A.; Stone, R.M.; Altman, J.K.; Roboz, G.J.; Patel, M.R.; Collins, R.; Flinn, I.W.; et al. Molecular remission and response patterns in patients with mutant- IDH2 acute myeloid leukemia treated with enasidenib. Blood 2019, 133, 676-687. [CrossRef] [PubMed]

117. Pollyea, D.A.; Tallman, M.S.; de Botton, S.; Kantarjian, H.M.; Collins, R.; Stein, A.S.; Frattini, M.G.; Xu, Q.; Tosolini, A.; See, W.L.; et al. Enasidenib, an inhibitor of mutant IDH2 proteins, induces durable remissions in older patients with newly diagnosed acute myeloid leukemia. Leukemia 2019, 33, 2575-2584. [CrossRef]

118. Stein, E.M.; DiNardo, C.D.; Fathi, A.T.; Mims, A.S.; Pratz, K.W.; Savona, M.R.; Stein, A.S.; Stone, R.M.; Winer, E.S.; Seet, C.S.; et al. Ivosidenib or enasidenib combined with intensive chemotherapy in patients with newly diagnosed AML: A phase 1 study. Blood 2020, 137, 1792-1803. [CrossRef]

119. Irvine, D.A.; Copland, M. Targeting hedgehog in hematologic malignancy. Blood 2012, 119, 2196-2204. [CrossRef]

120. Fukushima, N.; Minami, Y.; Kakiuchi, S.; Kuwatsuka, Y.; Hayakawa, F.; Jamieson, C.; Kiyoi, H.; Naoe, T. Small-molecule Hedgehog inhibitor attenuates the leukemia-initiation potential of acute myeloid leukemia cells. Cancer Sci. 2016, 107, 1422-1429. [CrossRef]

121. Martinelli, G.; Oehler, V.G.; Papayannidis, C.; Courtney, R.; Shaik, M.N.; Zhang, X.; O'Connell, A.; McLachlan, K.R.; Zheng, X.; Radich, J.; et al. Treatment with PF-04449913, an oral smoothened antagonist, in patients with myeloid malignancies: A phase 1 safety and pharmacokinetics study. Lancet Haematol. 2015, 2, e339-e346. [CrossRef]

122. Cortes, J.E.; Heidel, F.H.; Hellmann, A.; Fiedler, W.; Smith, B.D.; Robak, T.; Montesinos, P.; Pollyea, D.A.; DesJardins, P.; Ottmann, O.; et al. Randomized comparison of low dose cytarabine with or without glasdegib in patients with newly diagnosed acute myeloid leukemia or high-risk myelodysplastic syndrome. Leukemia 2019, 33, 379-389. [CrossRef]

123. Sallman, D.A.; Komrokji, R.S.; Sweet, K.L.; Mo, Q.; McGraw, K.L.; Duong, V.H.; Zhang, L.; Nardelli, L.A.; Padron, E.; List, A.F.; et al. A phase 2 trial of the oral smoothened inhibitor glasdegib in refractory myelodysplastic syndromes (MDS). Leuk. Res. 2019, 81, 56-61. [CrossRef]

124. Cortes, J.E.; Heidel, F.H.; Fiedler, W.; Smith, B.D.; Robak, T.; Montesinos, P.; Candoni, A.; Leber, B.; Sekeres, M.A.; Pollyea, D.A.; et al. Survival outcomes and clinical benefit in patients with acute myeloid leukemia treated with glasdegib and low-dose cytarabine according to response to therapy. J. Hematol. Oncol. 2020, 13, 1-12. [CrossRef]

125. Kent, A.; Vasu, S.; Schatz, D.; Monson, N.; Devine, S.; Smith, C.; Gutman, J.A.; Pollyea, D.A. Glasdegib as maintenance therapy for patients with AML and MDS patients at high risk for postallogeneic stem cell transplant relapse. Blood Adv. 2020, 4, 3102-3108. [CrossRef]

126. Pollyea, D.A.; Stevens, B.M.; Jones, C.L.; Winters, A.; Pei, S.; Minhajuddin, M.; D’Alessandro, A.; Culp-Hill, R.; Riemondy, K.A.; Gillen, A.E.; et al. Venetoclax with azacitidine disrupts energy metabolism and targets leukemia stem cells in patients with acute myeloid leukemia. Nat. Med. 2018, 24, 1859-1866. [CrossRef]

127. Wei, A.H.; Chua, C.C.; Tiong, I.S.; Fong, C.Y.; Ting, S.B.; Macraild, S.; Salmon, J.M.; Ivey, A.; Nguyen, J.; Yuen, F.; et al. Molecular Patterns of Response and Outcome in the Chemotherapy and venetoclax in Elderly AML Trial (CAVEAT study). Blood 2018, 132, 333. [CrossRef]

128. DiNardo, C.D.; Pratz, K.; Pullarkat, V.; Jonas, B.A.; Arellano, M.; Becker, P.S.; Frankfurt, O.; Konopleva, M.; Wei, A.H.; Kantarjian, H.M.; et al. venetoclax combined with decitabine or azacitidine in treatment-naive, elderly patients with acute myeloid leukemia. Blood 2019, 133, 7-17. [CrossRef]

129. Wei, A.H.; Strickland, S.A.; Hou, J.Z.; Fiedler, W.; Lin, T.L.; Walter, R.B.; Enjeti, A.; Tiong, I.S.; Savona, M.; Lee, S.; et al. venetoclax Combined With Low-Dose Cytarabine for Previously Untreated Patients With Acute Myeloid Leukemia: Results From a Phase Ib/II Study. J. Clin. Oncol. Off. J. Am. Soc. Clin. Oncol. 2019, 37, 1277-1284. [CrossRef] [PubMed]

130. Aboudalle, I.; Konopleva, M.Y.; Kadia, T.M.; Naqvi, K.; Vaughan, K.; Kurt, M.; Cavazos, A.; Pierce, S.A.; Takahashi, K.; Masarova, L.; et al. A Phase Ib/II Study of the BCL-2 Inhibitor venetoclax in Combination with Standard Intensive AML Induction/Consolidation Therapy with FLAG-IDA in Patients with Newly Diagnosed or Relapsed/Refractory AML. Blood 2019, 134, 176. [CrossRef]

131. Kadia, T.M.; Cortes, J.E.; Konopleva, M.Y.; Borthakur, G.M.; Pemmaraju, N.; Daver, N.G.; Bravo, G.M.; Issa, G.C.; Naqvi, K.; Short, N.J.; et al. Venetoclax Combined with Cladribine + Low Dose AraC (LDAC) Alternating with 5-Azacytidine Produces High Rates of Minimal Residual Disease (MRD) Negative Complete Remissions (CR) in Older Patients with Newly Diagnosed Acute Myeloid Leukemia (AML). Blood 2019, 134, 2647. [CrossRef]

132. Lachowiez, C.A.; Borthakur, G.; Loghavi, S.; Zeng, Z.; Kadia, T.M.; Masarova, L.; Takahashi, K.; Tippett, G.D.; Naqvi, K.; Bose, P.; et al. Phase Ib/II study of the IDH1-mutant inhibitor ivosidenib with the BCL2 inhibitor venetoclax +/- azacitidine in IDH1-mutated hematologic malignancies. J. Clin. Oncol. 2020, 38, 7500. [CrossRef]

133. Chyla, B.; Daver, N.; Doyle, K.; McKeegan, E.; Huang, X.; Ruvolo, V.; Wang, Z.; Chen, K.; Souers, A.; Leverson, J.; et al. Genetic Biomarkers Of Sensitivity and Resistance to venetoclax Monotherapy in Patients With Relapsed Acute Myeloid Leukemia. Am. J. Hematol. 2018, 93, E202-E205. [CrossRef] [PubMed]

134. Perl, A.E.; Daver, N.G.; Pratz, K.W.; Maly, J.; Hong, W.; Bahceci, E.; Tong, B.; Tian, T.; Dilley, K. venetoclax in Combination with gilteritinib in Patients with Relapsed/Refractory Acute Myeloid Leukemia: A Phase 1b Study. Blood 2019, 134, 3910. [CrossRef]

135. Dangl, M.; Chien, Y.; Lehmann, C.; Friess, T. Abstract 5505: Synergistic anticancer activity of clinical stage, non-genotoxic apoptosis inducing agents RG7388 (MDM2 antagonist) and ABT-199 (GDC-0199, BCL2 inhibitor) in p53 wild-type AML tumor models. Cancer Res. 2014, 74, 5505. [CrossRef] 
136. Pan, R.; Ruvolo, V.; Mu, H.; Leverson, J.D.; Nichols, G.; Reed, J.C.; Konopleva, M.; Andreeff, M. Synthetic Lethality of Combined Bcl-2 Inhibition and p53 Activation in AML: Mechanisms and Superior Antileukemic Efficacy. Cancer Cell 2017, 32, 748-760.e6. [CrossRef] [PubMed]

137. Daver, N.G.; Pollyea, D.A.; Garcia, J.S.; Jonas, B.A.; Yee, K.W.L.; Fenaux, P.; Assouline, S.; Vey, N.; Olin, R.; Roboz, G.J.; et al. Safety, Efficacy, Pharmacokinetic (PK) and Biomarker Analyses of BCL2 Inhibitor venetoclax (Ven) Plus MDM2 Inhibitor Idasanutlin (idasa) in Patients (pts) with Relapsed or Refractory (R/R) AML: A Phase Ib, Non-Randomized, Open-Label Study. Blood 2018, 132, 767. [CrossRef]

138. Platzbecker, U.; Middeke, J.M.; Sockel, K.; Herbst, R.; Wolf, D.; Baldus, C.D.; Oelschlägel, U.; Mütherig, A.; Fransecky, L.; Noppeney, R.; et al. Measurable residual disease-guided treatment with azacitidine to prevent haematological relapse in patients with myelodysplastic syndrome and acute myeloid leukaemia (RELAZA2): An open-label, multicentre, phase 2 trial. Lancet Oncol. 2018, 19, 1668-1679. [CrossRef]

139. Sockel, K.; Wermke, M.; Radke, J.; Kiani, A.; Schaich, M.; Bornhäuser, M.; Ehninger, G.; Thiede, C.; Platzbecker, U. Minimal residual disease-directed preemptive treatment with azacitidine in patients with NPM1-mutant acute myeloid leukemia and molecular relapse. Haematologica 2011, 96, 1568-1570. [CrossRef] [PubMed]

140. Blum, W.; Sanford, B.L.; Klisovic, R.; DeAngelo, D.J.; Uy, G.; Powell, B.L.; Stock, W.; Baer, M.R.; Kolitz, J.E.; Wang, E.S.; et al. Maintenance therapy with decitabine in younger adults with acute myeloid leukemia in first remission: A phase 2 Cancer and Leukemia Group B Study (CALGB 10503). Leukemia 2017, 31, 34-39. [CrossRef] [PubMed]

141. Zhang, L.; Conejo-Garcia, J.R.; Katsaros, D.; Gimotty, P.A.; Massobrio, M.; Regnani, G.; Makrigiannakis, A.; Gray, H.; Schlienger, K.; Liebman, M.N.; et al. Intratumoral T cells, recurrence, and survival in epithelial ovarian cancer. N. Engl. J. Med. 2003, 348, 203-213. [CrossRef] [PubMed]

142. Lamble, A.J.; Lind, E.F. Targeting the Immune Microenvironment in Acute Myeloid Leukemia: A Focus on T Cell Immunity. Front. Oncol. 2018, 8, 8. [CrossRef]

143. Schumacher, K.; Haensch, W.; Röefzaad, C.; Schlag, P.M. Prognostic significance of activated CD8(+) T cell infiltrations within esophageal carcinomas. Cancer Res. 2001, 61, 3932-3936.

144. Ismail, M.M.; Abdulateef, N.A.B. Bone marrow T-cell percentage: A novel prognostic indicator in acute myeloid leukemia. Int. J. Hematol. 2017, 105, 453-464. [CrossRef]

145. Robert, C.; Long, G.V.; Brady, B.; Dutriaux, C.; Maio, M.; Mortier, L.; Hassel, J.C.; Rutkowski, P.; McNeil, C.; Kalinka-Warzocha, E.; et al. Nivolumab in previously untreated melanoma without BRAF mutation. N. Engl. J. Med. 2015, 372, 320-330. [CrossRef]

146. Borghaei, H.; Paz-Ares, L.; Horn, L.; Spigel, D.R.; Steins, M.; Ready, N.E.; Chow, L.Q.; Vokes, E.E.; Felip, E.; Holgado, E.; et al. Nivolumab versus Docetaxel in Advanced Nonsquamous Non-Small-Cell Lung Cancer. N. Engl. J. Med. 2015, 373, 1627-1639. [CrossRef] [PubMed]

147. Taube, J.M.; Klein, A.; Brahmer, J.R.; Xu, H.; Pan, X.; Kim, J.H.; Chen, L.; Pardoll, D.M.; Topalian, S.L.; Anders, R.A. Association of PD-1, PD-1 ligands, and other features of the tumor immune microenvironment with response to anti-PD-1 therapy. Clin. Cancer Res. Off. J. Am. Assoc. Cancer Res. 2014, 20, 5064-5074. [CrossRef] [PubMed]

148. Alatrash, G.; Daver, N.; Mittendorf, E.A. Targeting Immune Checkpoints in Hematologic Malignancies. Pharmacol. Rev. 2016, 68, 1014-1025. [CrossRef]

149. Graf, M.; Reif, S.; Hecht, K.; Pelka-Fleischer, R.; Kroell, T.; Pfister, K.; Schmetzer, H. High expression of costimulatory molecules correlates with low relapse-free survival probability in acute myeloid leukemia (AML). Ann. Hematol. 2005, 84, 287-297. [CrossRef]

150. Whiteway, A.; Corbett, T.; Anderson, R.; Macdonald, I.; Prentice, H.G. Expression of co-stimulatory molecules on acute myeloid leukaemia blasts may effect duration of first remission. Br. J. Haematol. 2003, 120, 442-451. [CrossRef] [PubMed]

151. Chen, X.; Liu, S.; Wang, L.; Zhang, W.; Ji, Y.; Ma, X. Clinical significance of B7-H1 (PD-L1) expression in human acute leukemia. Cancer Biol. Ther. 2008, 7, 622-627. [CrossRef]

152. Yang, H.; Bueso-Ramos, C.; DiNardo, C.; Estecio, M.R.; Davanlou, M.; Geng, Q.R.; Fang, Z.; Nguyen, M.; Pierce, S.; Wei, Y.; et al. Expression of PD-L1, PD-L2, PD-1 and CTLA4 in myelodysplastic syndromes is enhanced by treatment with hypomethylating agents. Leukemia 2014, 28, 1280-1288. [CrossRef] [PubMed]

153. Daver, N.; Basu, S.; Garcia-Manero, G.; Cortes, J.; Ravandi, F.; Kornblau, S.; Konopleva, M.; Andreeff, M.; Borthakur, M.; Jain, N.; et al. Abstract 3205: Defining the immune checkpoint landscape of acute myeloid leukemia (AML). Cancer Res. 2016, 76, 3205. [CrossRef]

154. Kanakry, C.G.; Hess, A.D.; Gocke, C.D.; Thoburn, C.; Kos, F.; Meyer, C.; Briel, J.; Luznik, L.; Smith, B.D.; Levitsky, H.; et al. Early lymphocyte recovery after intensive timed sequential chemotherapy for acute myelogenous leukemia: Peripheral oligoclonal expansion of regulatory T cells. Blood 2011, 117, 608-617. [CrossRef] [PubMed]

155. Shenghui, Z.; Yixiang, H.; Jianbo, W.; Kang, Y.; Laixi, B.; Yan, Z.; Xi, X. Elevated frequencies of CD4 $4^{+}$CD25 $5^{+}$CD127lo regulatory $\mathrm{T}$ cells is associated to poor prognosis in patients with acute myeloid leukemia. Int. J. Cancer 2011, 129, 1373-1381. [CrossRef] [PubMed]

156. Szczepanski, M.J.; Szajnik, M.; Czystowska, M.; Mandapathil, M.; Strauss, L.; Welsh, A.; Foon, K.A.; Whiteside, T.L.; Boyiadzis, M. Increased frequency and suppression by regulatory $\mathrm{T}$ cells in patients with acute myelogenous leukemia. Clin. Cancer Res. Off. J. Am. Assoc. Cancer Res. 2009, 15, 3325-3332. [CrossRef] 
157. Boddu, P.; Kantarjian, H.; Garcia-Manero, G.; Allison, J.; Sharma, P.; Daver, N. The emerging role of immune checkpoint based approaches in AML and MDS. Leuk. Lymphoma 2018, 59, 790-802. [CrossRef]

158. Vidriales, M.B.; Orfao, A.; López-Berges, M.C.; González, M.; Hernandez, J.M.; Ciudad, J.; López, A.; Moro, M.J.; Martínez, M.; San Miguel, J.F. Lymphoid subsets in acute myeloid leukemias: Increased number of cells with NK phenotype and normal T-cell distribution. Ann. Hematol. 1993, 67, 217-222. [CrossRef]

159. Le Dieu, R.; Taussig, D.C.; Ramsay, A.G.; Mitter, R.; Miraki-Moud, F.; Fatah, R.; Lee, A.M.; Lister, T.A.; Gribben, J.G. Peripheral blood $\mathrm{T}$ cells in acute myeloid leukemia (AML) patients at diagnosis have abnormal phenotype and genotype and form defective immune synapses with AML blasts. Blood 2009, 114, 3909-3916. [CrossRef]

160. Williams, P.; Basu, S.; Garcia-Manero, G.; Hourigan, C.S.; Oetjen, K.A.; Cortes, J.E.; Ravandi, F.; Jabbour, E.J.; Al-Hamal, Z.; Konopleva, M.; et al. The distribution of T-cell subsets and the expression of immune checkpoint receptors and ligands in patients with newly diagnosed and relapsed acute myeloid leukemia. Cancer 2019, 125, 1470-1481. [CrossRef]

161. Schnorfeil, F.M.; Lichtenegger, F.S.; Emmerig, K.; Schlueter, M.; Neitz, J.S.; Draenert, R.; Hiddemann, W.; Subklewe, M. T cells are functionally not impaired in AML: Increased PD-1 expression is only seen at time of relapse and correlates with a shift towards the memory T cell compartment. J. Hematol. Oncol. 2015, 8, 93. [CrossRef]

162. Panoskaltsis, N.; Reid, C.D.; Knight, S.C. Quantification and cytokine production of circulating lymphoid and myeloid cells in acute myelogenous leukaemia. Leukemia 2003, 17, 716-730. [CrossRef]

163. Deng, M.; Gui, X.; Kim, J.; Xie, L.; Chen, W.; Li, Z.; He, L.; Chen, Y.; Chen, H.; Luo, W.; et al. LILRB4 signalling in leukaemia cells mediates T cell suppression and tumour infiltration. Nature 2018, 562, 605-609. [CrossRef] [PubMed]

164. Kong, Y.; Zhang, J.; Claxton, D.F.; Ehmann, W.C.; Rybka, W.B.; Zhu, L.; Zeng, H.; Schell, T.D.; Zheng, H. PD-1(hi)TIM-3(+) T cells associate with and predict leukemia relapse in AML patients post allogeneic stem cell transplantation. Blood Cancer, J. 2015, 5, e330. [CrossRef]

165. Zhou, Q.; Munger, M.E.; Veenstra, R.G.; Weigel, B.J.; Hirashima, M.; Munn, D.H.; Murphy, W.J.; Azuma, M.; Anderson, A.C.; Kuchroo, V.K.; et al. Coexpression of Tim-3 and PD-1 identifies a CD8+ T-cell exhaustion phenotype in mice with disseminated acute myelogenous leukemia. Blood 2011, 117, 4501-4510. [CrossRef]

166. Behrmann, L.; Wellbrock, J.; Fiedler, W. Acute Myeloid Leukemia and the Bone Marrow Niche-Take a Closer Look. Front. Oncol. 2018, 8, 444. [CrossRef]

167. Chokr, N.; Patel, R.; Wattamwar, K.; Chokr, S. The Rising Era of Immune Checkpoint Inhibitors in Myelodysplastic Syndromes. Adv. Hematol. 2018, 2018, 1-10. [CrossRef] [PubMed]

168. Saudemont, A.; Quesnel, B. In a model of tumor dormancy, long-term persistent leukemic cells have increased B7-H1 and B7.1 expression and resist CTL-mediated lysis. Blood 2004, 104, 2124-2133. [CrossRef] [PubMed]

169. Kadia, T.M.; Cortes, J.E.; Ghorab, A.; Ravandi, F.; Jabbour, E.; Daver, N.G.; Alvarado, Y.; Ohanian, M.; Konopleva, M.; Kantarjian, H.M. Nivolumab (Nivo) maintenance (maint) in high-risk (HR) acute myeloid leukemia (AML) patients. J. Clin. Oncol. 2018, 36, 7014. [CrossRef]

170. Soiffer, R.J.; Chen, Y.B. Pharmacologic agents to prevent and treat relapse after allogeneic hematopoietic cell transplantation. Blood Adv. 2017, 1, 2473-2482. [CrossRef] [PubMed]

171. Soiffer, R.J.; Davids, M.S.; Chen, Y.B. Tyrosine kinase inhibitors and immune checkpoint blockade in allogeneic hematopoietic cell transplantation. Blood 2018, 131, 1073-1080. [CrossRef]

172. Bernasconi, P.; Borsani, O. Immune Escape after Hematopoietic Stem Cell Transplantation (HSCT): From Mechanisms to Novel Therapies. Cancers 2019, 12, 69. [CrossRef]

173. Toffalori, C.; Cavattoni, I.; Deola, S.; Mastaglio, S.; Giglio, F.; Mazzi, B.; Assanelli, A.; Peccatori, J.; Bordignon, C.; Bonini, C.; et al. Genomic loss of patient-specific HLA in acute myeloid leukemia relapse after well-matched unrelated donor HSCT. Blood 2012, 119, 4813-4815. [CrossRef]

174. Vago, L.; Perna, S.K.; Zanussi, M.; Mazzi, B.; Barlassina, C.; Stanghellini, M.T.; Perrelli, N.F.; Cosentino, C.; Torri, F.; Angius, A.; et al. Loss of mismatched HLA in leukemia after stem-cell transplantation. N. Engl. J. Med. 2009, 361, 478-488. [CrossRef] [PubMed]

175. Davids, M.S.; Kim, H.T.; Bachireddy, P.; Costello, C.; Liguori, R.; Savell, A.; Lukez, A.P.; Avigan, D.; Chen, Y.B.; McSweeney, P.; et al. Ipilimumab for Patients with Relapse after Allogeneic Transplantation. N. Engl. J. Med. 2016, 375, 143-153. [CrossRef]

176. Bashey, A.; Medina, B.; Corringham, S.; Pasek, M.; Carrier, E.; Vrooman, L.; Lowy, I.; Solomon, S.R.; Morris, L.E.; Holland, H.K.; et al. CTLA4 blockade with ipilimumab to treat relapse of malignancy after allogeneic hematopoietic cell transplantation. Blood 2009, 113, 1581-1588. [CrossRef] [PubMed]

177. Albring, J.C.; Inselmann, S.; Sauer, T.; Schliemann, C.; Altvater, B.; Kailayangiri, S.; Rössig, C.; Hartmann, W.; Knorrenschild, J.R.; Sohlbach, K.; et al. PD-1 checkpoint blockade in patients with relapsed AML after allogeneic stem cell transplantation. Bone Marrow Transpl. 2017, 52, 317-320. [CrossRef] [PubMed]

178. Herbaux, C.; Gauthier, J.; Brice, P.; Drumez, E.; Ysebaert, L.; Doyen, H.; Fornecker, L.; Bouabdallah, K.; Manson, G.; Ghesquières, H.; et al. Efficacy and tolerability of nivolumab after allogeneic transplantation for relapsed Hodgkin lymphoma. Blood 2017, 129, 2471-2478. [CrossRef] [PubMed]

179. Haverkos, B.M.; Abbott, D.; Hamadani, M.; Armand, P.; Flowers, M.E.; Merryman, R.; Kamdar, M.; Kanate, A.S.; Saad, A.; Mehta, A.; et al. PD-1 blockade for relapsed lymphoma post-allogeneic hematopoietic cell transplant: High response rate but frequent GVHD. Blood 2017, 130, 221-228. [CrossRef] 